This document is the author's version of the following article:

Blanco, J., A. Sourdril, M. Deconchat, C. Barnaud, M. San Cristobal, E. Andrieu. 2020. How farmers feel about trees: Perceptions of ecosystem services and disservices associated with rural forests in southwestern France. Ecosystem Services 42:101066. https://doi.org/10.1016/j.ecoser.2020.101066

\title{
How farmers feel about trees: perceptions of ecosystem services and disservices associated with rural forests in southwestern France
}

\author{
Julien BLANCO ${ }^{\mathrm{a}, \mathrm{b}, 1,{ }^{*} \text {, Anne SOURDRIL }}{ }^{\mathrm{c}}$, Marc DECONCHAT ${ }^{\mathrm{a}, \mathrm{b}}$, Cécile BARNAUD ${ }^{\mathrm{a}, \mathrm{b}}$, Magali SAN \\ CRISTOBAL $^{\mathrm{a}, \mathrm{b}}$, Emilie ANDRIEU ${ }^{\mathrm{a}, \mathrm{b}}$ \\ ${ }^{a}$ Université de Toulouse, INRAE, UMR DYNAFOR, Castanet-Tolosan, France \\ ${ }^{\mathrm{b}}$ LTSER Zone Atelier «PYRÉNÉES GARONNE », 31320 Auzeville-Tolosane, France \\ ${ }^{\mathrm{c}}$ CNRS, UMR 7533 Ladyss, Université Paris Ouest-Nanterre, La Défense, 200, avenue de la \\ République, F-92001 Nanterre cedex, France \\ ${ }^{1}$ Current address: UMR CNRS 6554 LETG-Angers, UFR Sciences, Université d'Angers, France \\ * Corresponding author: Dr. Julien BLANCO, UMR CNRS 6554 LETG-Angers, UFR Sciences, \\ Université d'Angers, 2 boulevard Lavoisier, 49045 Angers, France \\ Email: julien.blanco.pro@gmail.com
}

\section{Co-authors' contacts:}

Anne Sourdril: asourdril@parisnanterre.fr

Marc Deconchat: marc.deconchat@inrae.fr

Cécile Barnaud: cecile.barnaud@inrae.fr

Magali San-Cristobal: magali.san-cristobal@inrae.fr

Emilie Andrieu: emilie.andrieu@inrae.fr

\begin{abstract}
Rural forests, including the wooded areas primarily managed by farmers (e.g. farm forests, hedgerows, isolated trees), are critical for the sustainability of agricultural landscapes. Yet with agricultural industrialization, rural forests have been in decline in many regions across Europe. To reverse this trend and promote the sustainable use of farmland, 'greening' measures have been introduced by the EU's Common Agricultural Policy (CAP) in recent years. However, their effectiveness depends on local farmers' values and reaction to these measures. In this study, we investigated the socio-cultural value accorded to rural forests in southwestern France by interviewing 19 farmers. The positive and negative contributions cited were categorized as ecosystem services/disservices and analyzed using qualitative and quantitative methods. The results indicate that farmers in this region have mixed views, as they cited 32 positive and 25 negative contributions (material and non-material) of rural forests. They felt trees provide services (e.g. erosion control, windbreak) and disservices to agriculture (e.g. decline in yield, damage to tractors and infrastructures). Depending on their farming practices, farmers had contrasting opinions on how to reconcile rural forests and agriculture. Our results suggest that CAP greening measures need to better target rural forest conservation and further adapt to local contexts.
\end{abstract}

\section{Keywords}

Agroforestry; trees on farm; local knowledge; landscape features; farmer studies; EU Common Agricultural Policy 


\section{Introduction}

The industrialization of agriculture since the Second World War has had a dramatic impact on European agricultural landscapes and their ability to sustain biodiversity (Cardinale et al., 2012). Agricultural mechanization and the extension of the surface area of farmland have contributed to a decrease in the wooded areas managed by farmers in several regions in Europe, including France (Blanco et al., 2019b; Burel et Baudry, 1990), the UK (Petit et al., 2003), and Spain (Arnaiz-Schmitz et al., 2018), as well as in Canada (Schmuki et al., 2002). In contrast, less productive agricultural land has experienced a dynamic of land abandonment and bush encroachment (e.g. Pereira and Martinho, 2017).

Wooded areas located in rural landscapes and managed by farmers (termed 'rural forests' in this study) include woods owned by farmers and what are commonly known as trees outside forests, such as hedgerows, isolated trees and copses. As rural forests play a key role in the functioning of agricultural landscapes, their decline has had a major impact on biodiversity and the supply of ecosystem services. For instance, hedgerows have an important function in pest and weed control and pollination (Dainese et al., 2017), as well as in creating biodiversity corridors (Dondina et al., 2016). They also provide significant non-material contributions to human well-being, such as improving the scenic value of landscapes (Oreszczyn et Lane, 2000). Isolated trees are also key assets for local biodiversity conservation, as they favor the circulation of species between forested patches (Manning et al., 2006; Sebek et al., 2016), and for local use, as they often provide edible fruits.

In recent years, one of the aims of the European Union's Common Agricultural Policy (CAP) has been to encourage rural forests to promote the sustainable use of farmland. Since 2013, a green payment scheme of Pillar I linked 30\% of the payment EU farmers receive from the CAP to three greening measures, including the reserve of 5\% of their arable land as Ecological Focus Areas (EFAs) (Articles 43 to 47 of EU Regulation No. 1307/2013). While these can include agroforestry areas and trees on farms (European Commission, 2017), the real contribution of these greening measures in promoting rural forests has been the subject of debate. For instance, in the case of wood pastures, the tree density mandated in the CAP is below the current tree density in several regions (Jakobsson et Lindborg, 2017). Moreover, the majority of EFA options available for European farmers encourage the implementation of productive types of EFA (i.e. nitrogen-fixing crops and catch crops) rather than unproductive ones (i.e. landscape features, including trees on farmland, Pe'er et al., 2017). This calls into question the relevance of such a global one-size-fits-all policy for local systems and for the conservation of rural forests. Furthermore, farmers are not driven solely by profit maximization and financial incentives (Home et al., 2014), and also behave on the basis of non-economic considerations, such as environmental concern (Chouinard et al., 2008) or preexisting socio-cultural norms and practices (Sourdril et al., 2012). Thus, in order to ensure effective agricultural policy that is suitable for specific contexts, it is important that studies take into account - beyond strictly economic considerations - the socio-cultural settings that influence how farmers perceive and interact with their environment, as well as how they may react to public policies.

The socio-cultural valuation of ecosystem services (ES) has proven effective in identifying the multiple values local people assign to ecosystems (Martin-Lopez et al., 2007). For example, a study on rural forests in Sweden showed that farmers value wood pastures for the provisioning ES they provide (e.g. meat and milk production), as well as their cultural ES, in particular their heritage value (Garrido et al., 2017). These perceptions may however differ between farmers. For instance, in a study in Paraguay, Da Ponte et al. (2017) reported contrasting uses and perceptions between individual farmers according to factors such as farm size and the type of farming system practiced. Moreover, some studies have highlighted that rural forests could also be perceived as a source of various ecosystem disservices (EDS) by farmers who mentioned actual or perceived negative impacts to their well-being (Shackleton et al., 2016; Teixeira et al., 2019). In Ethiopia, rural forests were perceived as a source of pests and wild mammals that affect crops and livestock (Ango et al., 2014; Dorresteijn et al., 2017). In France, some farmers blame trees for competing with crops and obstructing mechanized work (Blanco et al., 2019b). These mixed positive and negative perceptions of rural forests are more or less pronounced depending on the local technical, social and cultural context of the agricultural system (Dorresteijn et al., 2017). As 
a consequence, place-based research in different regions is crucial in order to guide locally relevant policy and enhance rural forest conservation.

In this study, we focused on the region of southwestern France to investigate how farmers perceive and manage rural forests in this area, collecting the information through in-depth interviews. A common practice in ES assessments is either to invite respondents to choose and/or rank the services to be assessed (and valued) from a list (La Notte et al., 2017), or to introduce the ES concept to respondents and ask them to explain their perceptions by means of this concept (e.g. Smith and Sullivan, 2014). While these practices can be very fruitful, they do not allow an assessment of whether the ES concept adequately reflects perceptions or effectively integrates different worldviews (Tadaki et al., 2017). To at least partly address these limitations, we used a semi-directed interview procedure that consisted of asking farmers about the advantages and disadvantages they associated with rural forests, using lay language and without introducing them to the ES concept. Their answers were then categorized as ES and EDS in a second step.

In this paper, we first present the information collected in the interviews, outlining how farmers in our case study manage rural forests and perceive the associated ES and EDS. Next, we investigate the variability in these perceptions, and how this reveals farmers' contrasting views. Finally, we discuss how the concept of ES/EDS can be used to analyze farmers' perceptions and attitudes, and how this can be used to guide both future research and agricultural policies.

\section{Materials and methods}

\subsection{STUDY SITE}

The study was conducted during Nov. 2016-March 2017 in southwestern France, near the city of Toulouse (4313'02.63"; $0^{\circ} 52^{\prime} 53.76^{\prime \prime}$, Figure 1), in the district of Aurignac, which is part of the 'Pyrénées-Garonne' Long-term Social-Ecological Research site. The southern part of the study area is hilly (200-400 $\mathrm{m}$ a.s.1.), lying in the Pyrenean piedmont. The terrain is a succession of alternating hills and valleys crossed by a dense network of watercourses, bordered to the south by the Pyrenees mountain chain. The northern area is the beginning of the Garonne valley and consists of plains and hills. The climate is temperate, with Atlantic and Mediterranean influences. The average annual temperature is $13.8^{\circ} \mathrm{C}$, and annual precipitation is $638 \mathrm{~mm}$ (Source: 1981-2010 data from the Toulouse-Blagnac meteorological station, https://donneespubliques.meteofrance.fr).

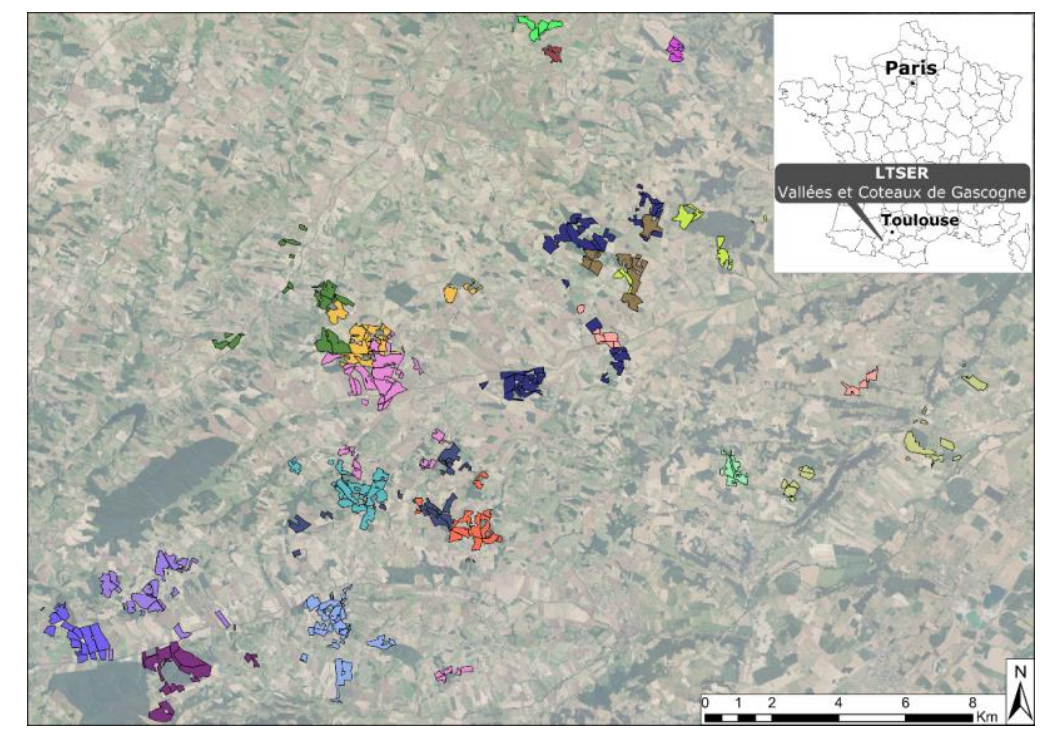

Figure 1: Location of the study site and map of the 19 farms managed by the interviewed farmers (each color represents a different farm, and each polygon is an agricultural block as defined by the Common Agricultural Policy). Background: aerial photograph (@ IGN 2015). 
Historically, mixed farming combining cereal cultivation (wheat, maize) and livestock rearing (for both milk and meat production) used to be the dominant system (Choisis et al., 2010). However, over recent decades, the number of farms has drastically declined, while the remaining farms have increased in size and become specialized in crop cultivation (Table S1, Suppl. material 1). More recently, society's increasing demand for organic products, as well as financial aid from the CAP to promote this type of farming, has led to the emergence of organic farms.

In this agricultural landscape, rural forests consist of small forest patches owned by farmers (i.e. farm forests) and rural trees outside forests (urban trees were not considered in the study). Most farms host a few woods that are scattered across the landscape and are mainly managed using a coppice-withstandards system. This management technique leads to woodland composed of (i) a lower story treated as coppice that provides firewood year-round, and (ii) an upper story of unevenly aged trees (the standards) that provide timber more occasionally (Du Bus de Warnaffe et al., 2006). Croplands and grasslands also contain trees that were traditionally managed for multiple purposes, especially to provide supplementary livestock forage, firewood, mushrooms, game and materials for handicrafts (Sourdril, 2008). Following our interviews with farmers, and for the sake of clarity, we organized rural forest components into five categories: forest (incl. forests and groves), isolated tree, hedgerow, riverbank, and edge tree. We use this terminology in the rest of the article and, for the sake of clarity, we use the term 'trees' in the text to refer to 'trees outside forests' that encompass isolated trees, hedgerows, riverbanks and edge trees (Table 1).

Table 1: Terminology used in this article to refer to the 5 rural forest components (including forests and trees outside forests) identified from farmers' interviews, and their associated definition within the scope of this study.

\begin{tabular}{cll}
\hline \hline Rural forest components & Definitions established from farmers' interviews \\
\hline & Isolated tree & $\begin{array}{l}\text { A single tree located in the middle, or on the border, of agricultural } \\
\text { plots (including pastures and crop fields). }\end{array}$ \\
Trees & Hedgerow & $\begin{array}{l}\text { A continuous and impassable row of trees and/or shrubs located in the } \\
\text { middle, or on the border, of agricultural plots. }\end{array}$ \\
Forests & $\begin{array}{l}\text { Riverbank } \\
\text { Edge trees }\end{array}$ & $\begin{array}{l}\text { Row of trees associated with a water course or a ditch. } \\
\text { that can be crossed by humans and livestock. }\end{array}$ \\
& $\begin{array}{l}\text { Forest (and } \\
\text { Forove) }\end{array}$ & $\begin{array}{l}\text { Woody area with trees and shrubs that could be used for firewood } \\
\text { and/or timber production. }\end{array}$ \\
\hline
\end{tabular}

\subsection{PILOT INTERVIEWS AND INTERVIEW DESIGN}

This study focused on farmers involved in crop cultivation and mixed farming, two major farming systems in the district of Aurignac along with cattle-based systems (Table S1, Suppl. material 1). To include diverse profiles, we selected both organic and conventional farmers. A total of 30 Aurignac farmers were contacted by phone and asked to participate in the study, of which 26 agreed to an initial face-to-face interview. These 26 pilot interviews of around 20 minutes in length took place between November 2016 and January 2017 and had the aim of (i) collecting data to build a more detailed interview protocol, and (ii) asking farmers' consent to participate in a second, more detailed interview. Of the 19 farmers who agreed to participate in the next phase, there were contrasting profiles in terms of farm surface area (from 13 to $250 \mathrm{ha}$ ), forest estate (from no forest to more than 12 ha of forest), age (from age 30 to 60+) and farming system practiced (Table S2, Suppl. material 1). However, most were male conventional farmers (there were 2 women and 3 organic farmers), which is explained by the low proportion of women farm managers and the scarcity of organic farms in this area (Choisis et al., 2010).

\subsection{INTERVIEW PROCEDURE}

The detailed interviews were conducted between January and March 2017, with each lasting around 2 hours. All interviews were recorded (except one due to technical issues) and consisted of four sections (Suppl. material 2). The first section collected general information about the farm (e.g. farm surface 
area, farming system, etc.) and the farmer (e.g. age, gender, secondary occupation, etc.). The second section aimed to collect spontaneous information on agricultural plots and rural forests on the farm. It was conducted as an open-ended discussion facilitated by an aerial photograph of the farm and its surroundings in which all rural forest components were visible ( 1/8000 resolution). The interviewer pointed out specific rural forest components in the photograph and asked the farmer about their associated advantages and disadvantages, as well as about management practices (section 2, Suppl. material 2). The third section of the interview was more directed, asking the farmer to list the contributions he/she associated with rural forests through two questions: (i) What advantages, or benefits, are particularly important to you regarding forested areas? (ii) What disadvantages, or constraints, are of particular concern to you? Because respondents may not spontaneously come up with everything that might be relevant during such an exercise (Diniz et al., 2015), the interviewer prompted them with suggestions (that the farmer could confirm or not) on the basis of information obtained during the second section of the interview. Finally, the fourth section of the interviews aimed at collecting data on the use of firewood and its commercialization. These interviews allowed us to collect, for each farmer, a list of advantages and disadvantages related to rural forests.

\subsection{HIERARCHICAL CLASSIFICATION OF POSITIVE AND NEGATIVE CONTRIBUTIONS}

The advantages and disadvantages listed by farmers were summarized and any synonyms were grouped together (Table S3 and S4, Suppl. material 1). This resulted in a final list of 32 positive contributions of rural forests (FPCs) and 25 negative contributions (FNCs). Following the hierarchical classification methods commonly used for ES (e.g. the CICES classification, Haines-Young and Potschin, 2018), we defined these contributions as specific ecosystem services or disservices (with codes) and grouped them into larger ES/EDS classes (Table 2). The FPCs that fit the ES definitions proposed in version 5.1 of the European CICES classification (Haines-Young and Potschin, 2018) were classified as ES. The FPCs that did not fit these definitions were classified as 'Other positive contributions'. Similarly, some FNCs corresponded to ecosystem disservices (defined as 'the ecosystem generated functions, processes and attributes that result in perceived or actual negative impacts on human wellbeing'; Shackleton et al., 2016). Due to the lack of a widely accepted EDS classification system, we adapted existing classifications (Gómez-Baggethun et Barton, 2013; Lyytimäki, 2014; Shackleton et al., 2016) to categorize these FNCs (Table 2). The FNCs that were not EDS were classified as 'Other negative contributions'.

Table 2: List of the rural forest positive (FPC) and negative contributions (FNC) identified from interviews with farmers and classified as ecosystem services (based on CICES 5.1, see Haines-Young and Potschin, 2018), disservices, and other positive and negative contributions. The N column represents the number of farmers who evoked the FPC/FNC. The codes were used in statistical analyses.

\begin{tabular}{|c|c|c|c|}
\hline & Classes of FPC and FNC (Code) & Positive \& negative contributions & $\mathbf{N}$ \\
\hline \multicolumn{2}{|c|}{18 classes of ES (CICES 5.1 code) } & \multicolumn{2}{|l|}{29 ecosystem services (Code) } \\
\hline \multirow{8}{*}{ 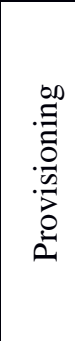 } & Wild plants - energy (S1.1.5.3) & Firewood (P1) & 17 \\
\hline & \multirow{3}{*}{ Wild plants - nutrition (S1.1.5.1) } & Fruits \& nuts (P2) & 11 \\
\hline & & Medicinal plants (P3) & 1 \\
\hline & & Mushrooms (P4) & 10 \\
\hline & \begin{tabular}{|l|} 
Wild animals - nutrition (S1.1.6.1) \\
\end{tabular} & Habitat for game (P5) & 4 \\
\hline & \multirow{2}{*}{$\begin{array}{l}\text { Wild plants - Fiber and other materials } \\
\text { (S1.1.5.2) }\end{array}$} & Wood \& timber (P6) & 5 \\
\hline & & Picket fence (P7) & 2 \\
\hline & Biomass for agricultural use (S1.3.1.1) & Pastoral areas \& resources $(\mathrm{P} 8)$ & 1 \\
\hline \multirow{5}{*}{ 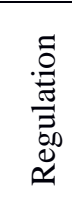 } & \multirow{3}{*}{$\begin{array}{l}\text { Regulation of air temperature and humidity } \\
\text { (S2.2.6.2) }\end{array}$} & Shade \& fresh air for humans (R1) & 5 \\
\hline & & Oxygen production and air quality (R2) & 6 \\
\hline & & Shade for reared animals (R3) & 4 \\
\hline & Control of erosion rates (S2.2.1.1) & Gully \& erosion control (R4) & 13 \\
\hline & & Habitat for wild birds (R5) & 5 \\
\hline
\end{tabular}




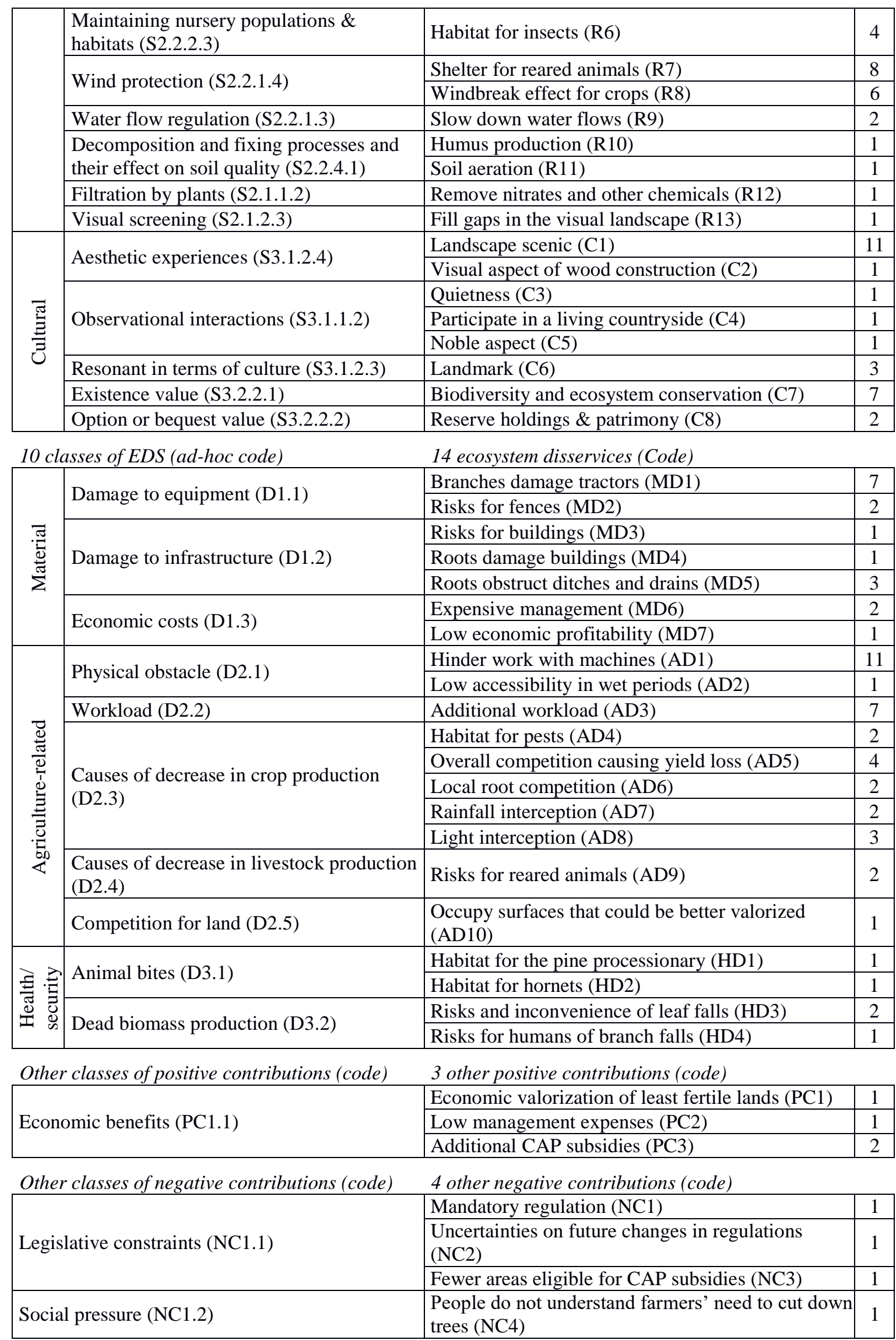




\subsection{ANALYSES OF FARMERS’ PERCEPTIONS REGARDING RURAL FORESTS}

To investigate how farmers perceived and managed rural forests, we combined both quantitative and qualitative analyses. First, we tested whether our sampling effort was sufficient to allow a good appraisal of the diversity of FPCs and FNCs perceived by farmers. To this end, we examined the level of data saturation with FLAME 1.2, an Add-In running in an EXCEL ${ }^{\circledR}$ environment that analyzes free-lists (Pennec et al., 2012). Data saturation may be understood as the point in our data collection (i.e. from a given number of interviews) when no new FPC or FNC was added by a new interview. As each farmer produced two lists, two distinct tests of data saturation were performed: one for FPCs and one for FNCs.

Secondly, a comprehensive qualitative analysis of interview data was performed to understand farmers' perceptions and management choices regarding rural forests. Interviews were transcribed and encoded with NVivo 11 (QSR International Pty Ltd., 1999-2017). Four axes structured the analysis: (i) the influence of FPCs and FNCs on farmers' well-being and activities, (ii) the type of forested areas associated with FPCs and FNCs, (iii) the rural forest management strategy and how it has changed, and (iv) divergences between farmers' discourse and perceptions.

Finally, to further explore variability in farmers' perceptions, Multiple Correspondence Analyses (MCA) were performed with the package FactoMineR (Husson et al., 2017) in R (R Core Team, 2018). For these analyses, each farmer was considered as an observation and was characterized by the FPCs and FNCs he/she cited as variables. Different MCAs were performed on the basis of different analytical options. We selected the results obtained from the most relevant MCA, i.e. the analytical option that reduced bias due to its sensitivity to rare items and that limited the number of variables. This MCA was performed with 19 observations (i.e. the 19 farmers), 25 active variables (i.e. the main classes of FPC and FNC cited by farmers) and 9 supplementary variables (i.e. the socio-economic attributes of farmers). For each observation and active variable, the value was ' 1 ' if the corresponding class of FPC/FNC was cited by the farmer, and ' 0 ' otherwise. Further details on analytical options and procedures are found in Suppl. material 3.

The following results are from these quantitative and qualitative analyses. The farmers' quotes were translated from French by a professional translator.

\section{Results}

\subsection{GENERAL RESULTS}

Farmers as a whole cited more FPCs $(\mathrm{N}=32)$ than FNCs $(\mathrm{N}=25)$ (Table 2). This trend was also true at an individual level (paired Student test, $\mathrm{t}$-value=10.0, $\mathrm{p}<0.01$ ) with, on average, 7.3 FPCs (SD=1.6; median=7) and 3.2 FNCs ( $\mathrm{SD}=1.1$; median=3) listed per farmer. According to the saturation test, the full set of 32 FPCs was obtained after interviewing 9 farmers, and the 25 FNCs after interviewing 8 farmers. Of the 32 FPCs, 5 were cited by more than $50 \%$ of the farmers (Table 2): firewood, gully and erosion control, fruits and nuts, landscape scenery and mushrooms. Only one FNC was cited by more than $50 \%$ of the farmers: the fact that trees hinder working with tractors.

Of the 32 FPCs, 29 were classified as ES, while 3 remained outside the scope of the CICES classification system. This resulted in 19 classes of FPC, including 18 classes of ES and 1 class of 'Other positive contributions' (Table 2). Of the 25 FNCs, 21 were classified as EDS, while 4 were outside the EDS definition. This resulted in 12 classes of FNC, including 10 classes of EDS and 2 classes of 'Other negative contributions' (Table 1). In total, we obtained 31 classes of rural forest contributions, including 25 cited more than once. Classes of FPC tended to be more frequently cited than classes of FNC (Figure 2). 


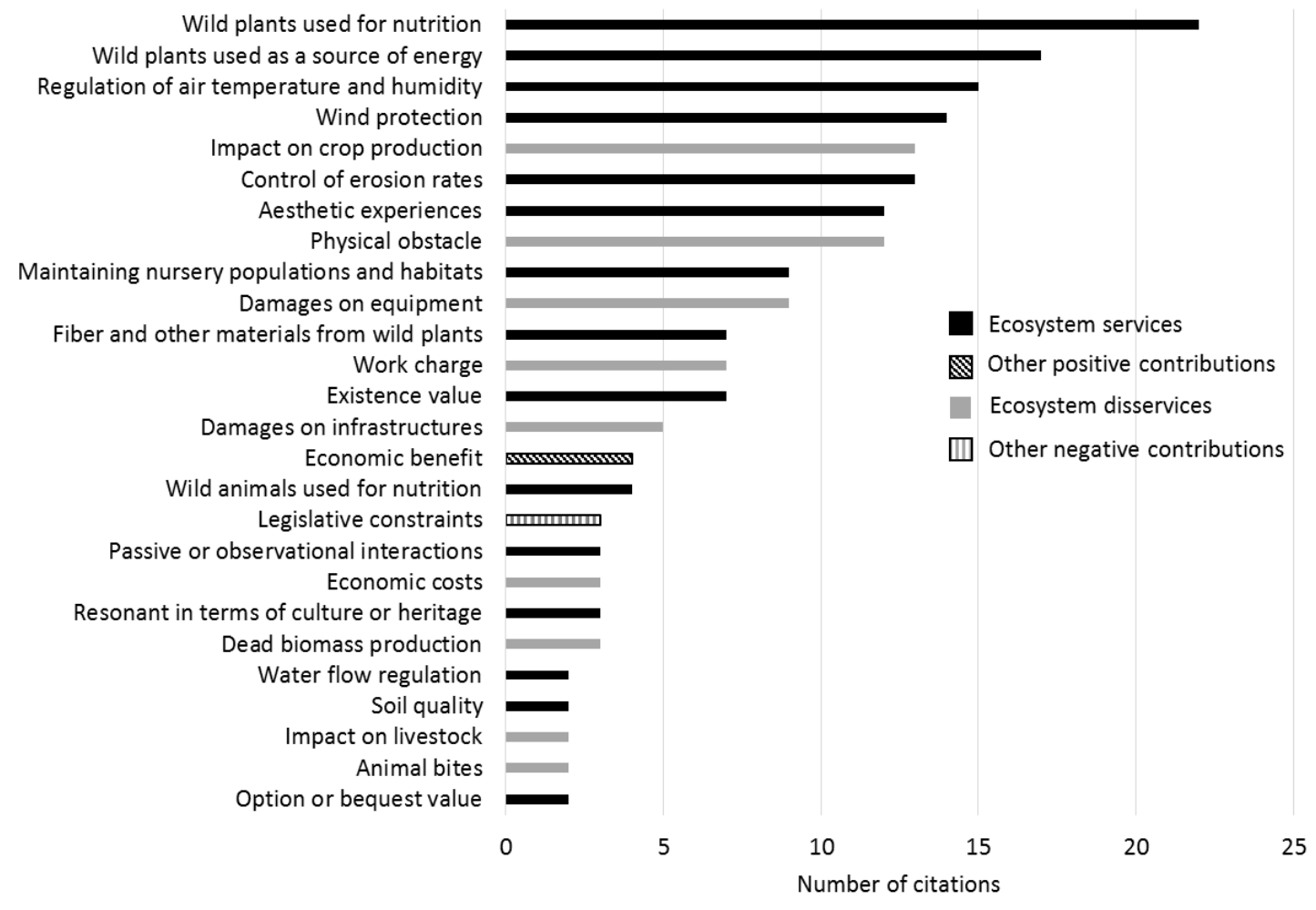

Figure 2: Number of times each class of rural forest contributions was cited by farmers. Only classes with at least two citations are represented. Black bars represent ecosystem services; black dashed-line bars represent other positive contributions; grey bars represent ecosystem disservices; grey dashed-lined bars represent other negative contributions.

\subsection{A SOURCE OF FIREWOOD AND TIMBER}

The most cited FPC was firewood ( $\mathrm{N}=17)$, whereas timber was less frequently mentioned $(\mathrm{N}=5)$. All but one farmer was using firewood at the time of the study, and 11 farmers stated it as their main source of energy for heating, complemented by oil or electric heating systems. Firewood is mainly harvested from crop-edge trees that require regular pruning. Pruning is done in winter, when agricultural work is low intensity: "We get a lot of wood for heating from around [field] edges, wood in streams, things like that. Or we prune back the branches that reach the tractor cabins and prevent us from working" (F09). In addition, trees on farmland and fallen forest trees constitute a substantial source of firewood: "If there is an oak that's been uprooted in the woods, I collect it to use it in my stove" (F09). Farmers therefore opportunistically make use of fallen trees that have to be removed from fields to allow agricultural work (Figure 3, left). Farmers also get firewood from preventive tree harvesting: "We just cut down a big oak by the outbuildings as it looked like it was going to fall down [...]. We did it with a friend who had a crane" (F12). They tend to prefer the option that takes the least time and technical equipment for firewood provisioning. As a consequence, most farmers no longer harvest firewood themselves by coppicing. One reason given is lack of time and the labor involved, as well as the arduous nature of the task: "I used to go [to the woods to get firewood], but now I don't go any more. I'm too old. It's too tiring. [...] Because you have to get it, put it in the log splitter, then collect the pieces and stack them..." (F02). Another reason is that tree harvesting demands skill (e.g. knowledge about how to cut down a tree properly and judge its fall) and special machines (e.g. a log splitter, an old tractor that can be taken into the woods) that farmers do not necessarily own. In these cases, three strategies were identified. First, farmers may ask a knowledgeable neighbor or relative for help: "If trees have to be cut down, I don't do that because I'm not much of an expert at that. But I have a neighbor who's a bit older than me who comes over and knows how to do it. If I tell him to cut down three or four trees, he'll cut them down" (F06). Requests for help such as this are part of a custom of reciprocal assistance: "If I have equipment, for instance, that my neighbor doesn't have, I'll go and help him get rid of a tree that has 
fallen down in his yard, or wherever. Then the neighbor will help me out too" (F08). Second, farmers may call upon informal loggers (especially retired farmers or unemployed relatives) who are paid in kind with half of the harvested wood. Third, farmers may rely on professional loggers who are paid on the basis of the number of cubic meters of stacked wood harvested: "A few years ago, we got some Portuguese [laborers] to come ... they cut down the trees and made it into firewood" (F06). The harvested firewood is mostly used for personal consumption, though two respondents sell part of it informally for cash.

As regards timber, in the last decade, only two farmers harvested it from trees on their land. Today, new buildings and homes are built mainly with purchased timber and non-wood materials. Yet according to the interviews, every 20 to 30 years farmers sell standing timber from their forests to local timber companies for additional income. After the timber is logged, farmers say they can "get some wood on the side" by collecting the biggest pruned branches for firewood (Figure 3, right). However, the farmers asked about this practice stated that selling timber is hardly profitable these days, which discourages some of them: "I tried one day to get an estimate for selling some wood [... but] when I saw the selling price it would get, I gave up [...]. It's nothing" (F04).
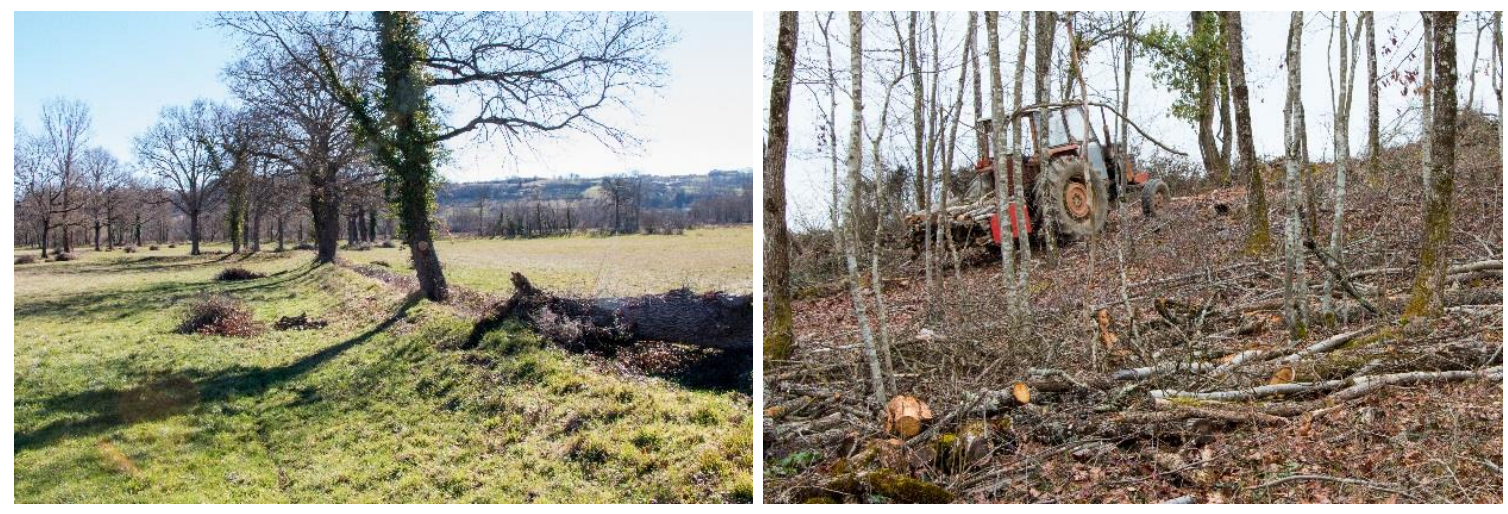

Figure 3: Left: Firewood resulting from edge trees pruning, and a fallen tree waiting to be harvested. Right: a farmer collecting remaining logs and branches from his forest after it has been harvested by a timber company. (Photographs from February 2017, J. Blanco).

\subsection{NON-LIGNEOUS PRODUCTS AND NON-MATERIAL CONTRIBUTIONS OF RURAL FORESTS}

Fruits and nuts were a frequently cited FPC. These are mostly collected from trees on farm, in particular isolated or edge trees. Walnuts (Juglans spp. L.), figs (Ficus carica L.), plums (Prunus domestica L.) and sloes (Prunus spinosa L.) were the most cited non-ligneous products. Fruits and nuts are collected, processed and used for personal consumption by families, or might be given to a neighbor in return for a service rendered. These uses encourage farmers to maintain fruit trees on their farms, notwithstanding certain associated disadvantages: "Yes, that's a fig tree. I drive around it [with the tractor]. It's been getting in my way for a long time now [...] though I don't mind getting the figs!" (F02). In addition, many farmers highlighted the environmental value of fruit trees, in particular for pollinators and frugivores: "We're really glad to see the fruit, even if we don't eat it. And the birds are happy. And the bees! The bees (laughs)! Because if us farmers don't do it, who's going to?" (F07).

Mushrooms were another non-ligneous forest product particularly appreciated by farmers. When the climate is favorable, farmers go to woodland areas to harvest them, either on their own land or outside of it. Likewise, both countryside and city dwellers frequently harvest mushrooms in farmers' woods: "Here, everyone goes to the woods to gather mushrooms, no one stops them [...] as long as they don't take them all" (F18). This practice is tolerated as long as people do not damage property (especially fences) or harvest large quantities to sell at local markets: "Here it's unbelievable - during mushroom season, when there are thunderstorms, [people collect them to] sell in the market. I can't stand that. [...] But when people get them for themselves, that's OK, it doesn't bother me" (F12). 
Finally, rural forests provide significant non-material services, in particular those related to scenic value and landscape identity: "The landscape is much prettier with a few woods and hedges than if it were bare! I'm not an ecologist, far from it, but I'm not a total destroyer either" (F18). Respondents consider rural forests to be integral to the undulating landscape, as they occupy hilly terrain that is difficult to cultivate mechanically. In this area, trees and hills are two inseparable characteristics, in contrast to the flat and deforested areas in the plain. The presence of trees testifies to the maintenance of the traditional activity of herding: "A cereal farmer [...] has big fields, with nothing in the middle to get in the way. While in the mixed crop-livestock farming we do, the livestock rearing always takes up about as much space as a wood - a parcel we can't plough - so we keep those parts" (F05).

\subsection{RURAL FOREST CONTRIBUTIONS TO AGRICULTURE}

From the viewpoint of the farmers we interviewed, rural forests contribute both positively and negatively to agriculture (Figure 2). Based on their own experiences and observations, farmers were prone to cite the positive effect of erosion control (Table 2): "There was a hedge there, and a track with a hedge over there. Further on there was a bank, but all that's been removed, and now when there's a thunderstorm, [... the earth] slides down to here" (F18). Aside from the role of rural forests in limiting erosion, farmers also stressed the impact of land use and tillage on erosion: "The erosion [...] also comes from the ways of working here. If you plough, there are a lot more gullies than if you just work the topsoil or use a light harrow, for instance. When you leave the organic matter on the surface, there's less gullying" (F09).

Rural forests were perceived as being an asset for livestock, in particular for their sheltering function. Interestingly, if some patches of forest are left open to cattle, for farmers the purpose of this practice is mainly for forest clearing, not initially to provide an additional forage area: "The advantage is that [the cows] go [into the wood, where] at least they trample the brambles - what little they can trample. The fact that the wood is cleared, to start with, allows grass to regrow there. Then the cows can go and eat this fresh grass" (F05). Another positive contribution considered important for agriculture is the role of rural forests as landmarks. Isolated trees mark specific features (such as springs), and hedgerows mark out farm boundaries. They also protect crops next to a grazing pasture: "With a neighbor who raises livestock, it's better to have a hedge than a fence, in the end. Because cattle can get through a fence, but they can't get through a hedge," (F08). On the other hand, farmers rarely mentioned the role of trees in sheltering useful insects, filtering pollution, or improving soil quality (Table 2): the exception was a 31year-old woman (i.e. the youngest respondent).

As regards negative contributions to agriculture, the first cited FNCs were related to the impact on mechanized cultivation of fields, as trees constitute physical obstacles that may damage tractors. Regular pruning is practiced to mitigate these FNCs: "[The hedges] cause us problems in places where we work with tractors. In the cabin - ping ping ping - we get banged about ... I have to cut them back a bit" (F05). However, regular pruning translates to extra cost and workload: "Every year you have to go over the hedges. It's 20 hours with the flail mower every year: 30 hours of work, the diesel fuel, the equipment $[\ldots]$ it costs quite a bit in the end if you really count it up" (F08). Some farmers consequently prefer to remove edge trees, which also enables them to extend their fields: "Over there, I pulled up a hedge; here there was another hedge that cut my field in two, so I pulled it up about ten years ago. This colza field was six fields to begin with - now there's only one" (F17). The other main FNCs cited concerned the negative impact of trees on crop production. Some farmers considered that trees compete with crops for light, nutrients and water, while others emphasized one or the other of these aspects in particular: "In a field of corn, you'll see a ring [where corn doesn't grow] around an oak. That shows you the spread of the roots - it's not because of the shade" (F04). In addition, farmers highlighted indirect FNCs, such as the fact that trees and woods shelter pests and wild mammals that can damage crops, especially roe deer.

\subsection{CONTRASTING PERCEPTIONS AND VIEWS OF FARMERS}

In addition to identifying the aspects that predominated in the farmers' discourse, our analyses revealed contrasting views between farmers. First, the MCA revealed a gradient spanning from organic farmers to farmers of conventional crop systems, with farmers in conventional mixed systems in an 
intermediate position (Figure 4A). Figure 4B and Table 3 highlight the active variables driving these patterns of variability, with the first axis tending to oppose a cluster of regulating and cultural ES from a cluster of negative contributions and lacking ES. Secondly, our qualitative analysis corroborated this trend, revealing contrasting views between farmers on how to balance FPCs and FNCs. On the one hand, some farmers promoted a 'land sparing' model, i.e. spatial separation of agriculture and forests: "I don't agree with inventorying the trees at field edges so that we can't cut them down when we want, but inventorying forests to limit cutting them down, like in the Amazon, I'm all in favor of that" (F08). These farmers were prone to criticizing CAP directives for being too constraining, and were expecting further legislative restrictions in the future: "So what's going on these days [is] you see [mechanical] diggers pulling up hedges and trees because [farmers are] anticipating future regulations" (F09). On the other hand, some farmers tended to criticize the 'land sparing' vision, highlighting its roots in the postwar agricultural model: "In our minds, we're still back in the intensive farming methods of the 1970s and 1980s. After the war, you had to produce enough to feed people, to get the economy going again, and I think this attitude is still there deep down" (F05). These farmers were particularly aware of the negative impact of tree removal and advocated for a compromise between trees and agriculture at field scale: "The old timers put in hedges, put up banks in the fields, [whereas] today we've got this problem with gully erosion. That's our doing, because we got rid of the hedges and the banks" (F18). They were more favorable to recent CAP developments, although they warned about unintended effects and strategies to bypass the rules (for example, in the mandate to dedicate $5 \%$ of arable land to areas beneficial to biodiversity, farmers have the option to leave land fallow rather than keeping trees or hedges): "Some farmers influenced by the CAP are afraid that if there's a yard of hedge that goes over into a field, they'll be penalized. [...] The CAP and the interpretation of the CAP have had a very harmful effect on the survival of hedges. There are some farmers with Ecological Focus Areas that they choose to leave fallow. [...] A lot of farmers would rather have zero trees [...] that's the perverse effect of the CAP on the landscape" (F03).

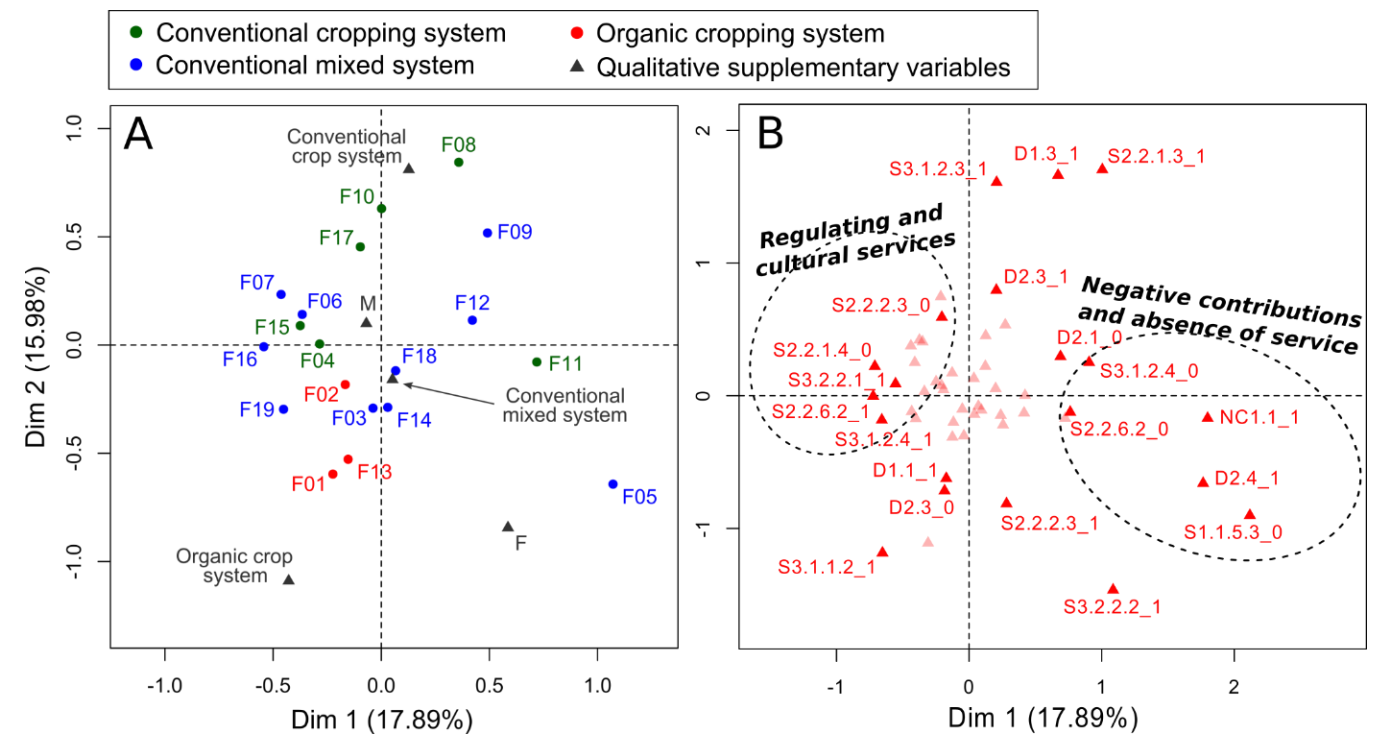

Figure 4: Multiple Correspondence Analysis outcomes:(A) Projections on the two first axes of the individuals (organic farmers in red; farmers with conventional cropping systems in green; farmers with conventional mixed systems in blue) and of the supplementary qualitative variables (i.e. gender (M/F) and farming system, grey triangles); (B) Graphs of the active categories to the first two axes of the MCA (red triangles: the 20 most contributive categories; light red triangles: the other categories). The codes used to identify the active variables are those presented in Table 2 . 
Table 3: Main contributors of the Multiple Correspondence Analysis for the two first axis (Dim 1 and Dim 2): only individuals and variables with a large quality of representation into the axes are reported (individuals with $\cos 2 *>0.5$, active variables with eta2 $¥>0.5$, supplementary qualitative variables with eta2 $>0.5$ and supplementary quantitative variables with $\mid$ cor $\mathbb{q} \mid>0.3)$.

\begin{tabular}{|c|c|c|c|c|c|c|c|c|}
\hline & \multicolumn{2}{|c|}{ Individuals } & \multicolumn{2}{|c|}{ Active variables } & \multicolumn{2}{|c|}{$\begin{array}{c}\text { Suppl. qualitative } \\
\text { variables }\end{array}$} & \multicolumn{2}{|c|}{$\begin{array}{c}\text { Suppl. quantitative } \\
\text { variables }\end{array}$} \\
\hline & Id & $\operatorname{Cos} 2$ & Id and name & Eta2 & Name & Eta2 & Name & Cor \\
\hline $\begin{array}{l}\text { Dim } 1 \\
(17.9 \%)\end{array}$ & F05 & 0.61 & $\begin{array}{l}\text { S1.1.5.3-Wild plant } \\
\text { for energy } \\
\text { S3.1.2.4-easthetic } \\
\text { experiences } \\
\text { NC1.1-legislative } \\
\text { constraints }\end{array}$ & $\begin{array}{l}0.53 \\
0.60 \\
0.61\end{array}$ & - & - & Age & -0.33 \\
\hline $\begin{array}{l}\operatorname{Dim} 2 \\
(16.0 \%)\end{array}$ & - & - & $\begin{array}{l}\text { D2.3-decrease in } \\
\text { crop production } \\
\text { D1.3-economic } \\
\text { costs }\end{array}$ & $\begin{array}{l}0.57 \\
0.52\end{array}$ & $\begin{array}{l}\text { Farming } \\
\text { system }\end{array}$ & 0.41 & $\begin{array}{c}\text { FarmArea } \\
\text { No of cited } \\
\text { FNC }\end{array}$ & $\begin{array}{l}0.30 \\
0.41\end{array}$ \\
\hline
\end{tabular}

* represents the quality of the representation for individuals on each axis.

$¥$ Square of the correlation ratio between each variable and each axis.

"Correlation coefficient between each quantitative variable and each axis.

\section{Discussion}

\subsection{THE MULTIPLE DIMENSIONS OF RURAL FOREST ES AND EDS TO FARMERS}

Our results found that the respondents perceive trees as providers of multiple both positive and negative contributions. These findings are consistent with other research conducted in farming communities in temperate and tropical environments (Garrido et al., 2017; Genin et al., 2013; Smith et Sullivan, 2014) and emphasize the complex interdependence between agricultural and forest systems.

Unsurprisingly, the most frequently cited FPCs were provisioning services, in particular for food and fuel, which are known to be important to local stakeholders and landowners who directly depend on ecosystems for their livelihood (Garrido et al., 2017). In line with other studies (Da Ponte et al., 2017; Dorresteijn et al., 2017; Garrido et al., 2017), we found that firewood is an important FPC to farmers, who mainly use it for personal consumption. Firewood effectively generates savings on energy expenses and allows the exploitation of byproducts from tree pruning, a necessary management practice for trees around the edges of agricultural plots. Thus, harvesting firewood has an undeniably rational economic basis, which may be linked to the willingness of farmers to maintain some traditional forestry uses (Andrieu et al., 2011).

Aside from provisioning services, several regulating ES were acknowledged by farmers, in particular those related to air temperature regulation, protection from wind, and erosion control. These services were generally seen as profitable to agriculture as they enhance some provisioning ES, especially food production.

At the same time, rural forests were also seen as a source of EDS by farmers, a reality that has been recognized in an increasing number of studies (Dorresteijn et al., 2017; Lugnot et Martin, 2013; Mackenzie et Ahabyona, 2012). The most frequently cited FNC - trees represent physical obstacles to mechanization - illustrates the difficulty of reconciling mechanized agriculture with trees (see also Ango et al., 2014) and confirms the link between the mechanization of agriculture and the decline of trees outside forests (Blanco et al., 2019b; Petit et al., 2003). The loss of agricultural production - caused by tree competition with crops or crop raiding by wildlife - was the second most frequent category of FNC cited by informants; this represents a major source of concern for farmers worldwide (Ango et al., 2016; Mackenzie et Ahabyona, 2012). Finally, two other frequently evoked FNCs were the additional work 
involved in rural forest management, as well as the additional costs associated with the damage caused by trees.

Another noteworthy result concerned the importance of non-material ES for farmers. As has been found elsewhere, farmers in the study region attach great importance to the landscape's scenic value and identity, as well as to traditional land-use practices, and rural forests play a part in this. Similar to other landscape components, they are a feature that farmers have inherited from previous generations and will transmit to subsequent generations. This heritage and legacy value occupies an important place in farmers' discourse, suggesting that their perceptions include a vision of the landscape's history as well as its future. This non-material contribution of rural forests was also embedded in certain provisioning ES. For instance, farmers continue to harvest firewood and collect fruits, nuts and mushrooms, not only to meet material needs, but also to maintain certain traditional practices and types of social interactions. These provisioning services could therefore be considered 'cultural subsistence services', i.e. provisioning ES that are deeply related to social traditions, beliefs and norms (Pascua et al., 2017). In our case study, we found that some provisioning ES (e.g. the harvesting of firewood from hedgerows) are partly valued by local stakeholders because of their underlying cultural value (e.g. the maintenance of mutual aid networks between farmers). As we based our categories on the CICES system, and to avoid double counting, these services were classified as provisioning ES, though they could equally have been classified as cultural subsistence services since both material and non-material aspects mattered to farmers. It is important to keep in mind that such classification choices may have a significant influence on the overall results of socio-cultural valuation studies.

\subsection{VARIABILITY IN FARMERS' PERCEPTIONS OF RURAL FOREST ES/EDS}

The study revealed variability in farmers' views and perceptions of rural forests, emphasizing the importance of studying individual perceptions rather than considering farmers as a homogeneous group of stakeholders (Vanclay, 2004). In the MCA (Figure 4B and Table 3), we observed a significant contribution of FNCs in explaining the variability between farmers. This result could be explained by the fact that FNCs were less frequently mentioned by farmers than FPCs, so they contributed more to the MCA's dimensions. In other words, the MCA highlighted that the consensus among farmers was lower for FNCs than FPCs. This result stresses the need to better take into account perceived EDS in socio-cultural valuation studies, so as to more accurately identify differences between people's perceptions, and ultimately to better understand the variability in their behavior.

Secondly, in accordance with other studies (e.g. Da Ponte et al., 2017), we found correlations between farmers' perceptions and the type of farming they practiced. Our qualitative analysis confirmed that farmers with a mixed crop-livestock farming system were more favorable to trees than farmers solely cultivating crops. This may be explained by the various ES that trees provide to livestock and by the low EDS associated with trees in pastures (in contrast with trees in cropland). This supports studies that have shown that the maintenance of diversified pastoral systems contributes to the conservation of farm trees (Hartel et al., 2017; Pfund et al., 2011). Furthermore, organic farmers tended to be more favorable to trees than conventional farmers. Yet, because our sample included only three organic farmers, confirming this result would require further research.

Finally, farmers differed in the options they envisioned as a way to reconcile rural forests and agriculture at landscape scale. While they all agreed on the necessity of managing trade-offs between agricultural production and tree maintenance, they advocated for either a 'land sharing' or a 'land sparing' scenario. Farmers that supported the former approach highlighted the multiple ES rural forests supply to agriculture and why this made them willing to bear the associated EDS. For instance, some farmers maintain isolated fruit trees in their fields notwithstanding the inconvenience for mechanized cultivation. Others purposely let hedgerows grow and do not manage them in order to enhance biodiversity despite an observed increase in pests and the risk of getting reduced CAP subsidies due to the loss of arable areas eligible to Pillar I direct payments. In contrast, farmers who argued for a 'land sparing' model emphasized the negative impact of rural forests on crop production and mechanized cultivation. They considered that many forested areas could be better exploited by converting them into agricultural land, leaving only the least fertile or least accessible land forested. For instance, one farmer 
had recently bought a forested parcel and planned to convert it to enlarge a crop field, arguing that agricultural areas should be cleared of trees and remain separate from forest areas. These different points of view echo current uncertainties regarding how to effectively reconcile food production and biodiversity conservation in agricultural landscapes and highlight the need for further research (Fischer et al., 2014).

\subsection{CHANGE AND STABILITY IN THE SUPPLY AND DEMAND OF ES}

Our findings highlighted both trends - continuity and change over time - in perceptions of the supply and demand of ES provided by rural forests. For example, respondents noted a pattern of change in firewood demand, which has decreased in recent decades as houses have been progressively equipped with fossil fuel-based central heating systems. Another example is that while people in the area used to use diverse forest products to make handicrafts or homemade alcohol or for forage (Sourdril, 2008), our interviews confirmed the virtual disappearance of these traditional practices and the resulting decline in rural forest domesticity (Sourdril et al., 2012). Some of these changes are associated with changes in French laws - for example, homemade alcohol production is now strictly regulated. Others are explained by the development of alternative options, in particular for firewood, handicrafts and livestock forage. As a consequence, these factors seem to have contributed to lowering the value farmers assign to rural forest ES. Similarly, changes in agricultural practices over recent decades (e.g. mechanization) seem to have reinforced certain FNCs. The expansion of the surface area of farms, alongside a decline in the available workforce due to rural exodus, have exacerbated the difficulty for farmers to properly manage woodlands. Because of the increase in cropland and the mechanization of cultivation, tree-crop competition has become a more salient issue for farmers, with a more significant impact on perceived farm profitability. Finally, the use of ever-larger machines has the result that trees further hinder mechanized work. As demand for particular ES has changed, farmers have adapted their farms, in particular by removing trees on farmland (Blanco et al., 2019b) and abandoning certain management practices dedicated to enhancing FPCs (e.g. local sylvicultural practices aimed at increasing wood production). These changes in farmers' practices have impacted the supply of ES/EDS, highlighting the critical role of human agency relative to ecosystem function in the services/disservices provided (Spangenberg et al., 2014).

Other perceptions of ES/EDS show stability over time, sometimes despite contextual changes. In some cases this is due to a certain disconnection between scientific and farmer knowledge. For example, over the last two decades, scientific literature has generally reached a consensus on the overall positive impact of hedgerows on crop yields (Baudry et al., 2000; Van Vooren et al., 2017), soil fertility (Torralba et al., 2016), and pollutant filtration (Brauman et al., 2007). Yet farmers either disagreed with these findings or were not aware of them. One reason for this gap lies in the fact that farmers' learning is mostly based on empirical observation and experience. For example, farmers realized the efficacy of hedgerows in controlling erosion as they observed the occurrence of landslides after their removal. But less visible effects are less likely to shift perceptions. As one farmer explained, a decrease in yields next to hedgerows (caused by local tree-crop competition) is more visible than an increase in yields in the middle of a field (due to the reduction of wind speed provided by the hedgerow). This is consistent with the findings of Salliou and Barnaud (2017) who reported poor farmer awareness regarding processes that are seemingly hard to grasp, such as landscape-scale biological control. A further factor is that farmers and scientists use different indicators to assess rural forest contributions. Farmers tend to consider the actual impacts of trees on their farms and overall activities: in terms of additional labor, required knowledge and skills, and economic returns (Salliou et Barnaud, 2017). In contrast, research focuses on woodland impact on biophysical processes, and generally overlooks the impact on farming activities. A final factor is certainly related to the loss of local knowledge associated with the modernization of agricultural systems on the one hand, and insufficient availability of scientific findings among farmers on the other. The transfer of research findings from the experimental context to realworld, local settings remains a particular challenge. While scientists have a role to play in ensuring this transmission of knowledge, it also requires the engagement of agricultural advisors and agencies that have frequent interactions with farmers and that favor changes in agricultural practices. 
To conclude, the poor awareness of farmers regarding some key positive contributions of rural forests to agriculture is worrisome: "lack of information affects people's abilities to place a value on ecosystem attributes" (Bingham et al., 1995). To tackle the challenge of conserving rural forests, research should aim to better integrate farmers' questions and concerns in order to produce knowledge that could be better operationalized locally (Duru et al., 2015). Engaging agricultural support agencies and agricultural advisors/consultants in this co-production process could further help to promote changes in farmers' practices.

\subsection{METHODOLOGICAL CHALLENGES AND IMPLICATIONS FOR RESEARCH}

Our results highlighted the complementarity of ES and EDS for understanding the perceptions and behavior of farming communities regarding rural forests. As Table 2 illustrates, the ES concept was quite effective to capture most of the FPCs cited by farmers. Only 3 FPCs were not considered as ES according to the definitions we used (Haines-Young et Potschin, 2018); these were related to benefits that farmers directly or indirectly derive from ecosystems or ES conservation (e.g. additional CAP subsidies). In contrast, the classification of FNCs as EDS was more challenging due to the lack of a widely accepted EDS conceptual framework and classification system. Just as ES are distinct from the benefits derived from them (e.g. firewood production is distinct from the economic benefits obtained by the sale of firewood), EDS should be distinct from the costs they induce (Campagne et al., 2018; Shackleton et al., 2016). Yet we found the delineation between the two was sometimes fuzzy. For example, we classified as EDS 'damage to tractors caused by trees', 'management costs' and 'additional workload'; however, they could be considered as a set of direct and indirect costs caused by the EDS 'growth of tree branches in fields'. While these kinds of considerations have received a lot of attention for ES and allowed the construction of widely accepted definitions of what ES are/are not, this work remains to be done for EDS (Blanco et al., 2019a).

A second challenging aspect concerns the methodology used in this study. We conducted in-depth interviews with 19 farmers, encountering each of them twice. This approach allowed a very fine-scale description of how farmers in the local area perceive rural forests and their behavior in relation to these, as well as a thorough understanding of the complexity of their management choices. However, the choice of a semi-structured interview protocol, to enable a mixed approach combining qualitative and quantitative analyses, required some trade-offs between the length of the interview necessary to uncover complex processes and perform a relevant qualitative analysis, and the number of interviews necessary to allow robust statistical analyses and a representative sample size. An examination of the level of data saturation ensured that our sample was large enough to permit a good overview of the FNCs and FPCs perceived by farmers, which required around 10 interviews (see section 3.1). We also targeted the region's dominant farming systems when selecting the respondents. Thus, we are quite confident that our results are illustrative of the farming community in the study area. Yet while the trends revealed by the MCA corroborated the qualitative analyses, it would be valuable in future research to increase the number of farmers in order to further test certain hypotheses, in particular regarding the influence of the type of farming system and gender on farmers' relationships with rural forests.

\subsection{IMPLICATIONS FOR AGRICULTURAL POLICIES}

Our findings revealed different attitudes among farmers regarding CAP greening measures. Most felt these imposed additional constraints and additional labor. While some farmers acknowledged these measures may have an overall positive impact on rural forest conservation, others were more skeptical and highlighted the unintended consequences of the policy in practice and bypass strategies. For example, as agricultural areas eligible for CAP payments can be reduced if the spread of hedgerows is not properly managed, some farmers prefer to remove them in favor of productive Ecological Focus Areas (EFAs) such as nitrogen-fixing crops and catch crops. Interview responses suggested that farmers were encouraged to do this by agricultural advisors from public agencies, confirming the reluctance of European farmers to classify rural forests as EFA (Pe'er et al., 2017). Thus, to better promote rural forest conservation, two different thresholds could be defined: a minimum area of productive types of EFA and a minimum area of unproductive types of EFA (i.e. specific landscape features such as hedgerows 
and isolated trees). Furthermore, rather than one-size-fits-all targets, these thresholds should take into account the specificity of local contexts and current realities: e.g. landscapes with a current high level of wooded areas should have higher targets than landscapes with a lower level of wooded areas. In this objective, a more bottom-up approach could be taken for deciding the most relevant thresholds for a specific region, based on the expertise of local agricultural advisors and support services.

Moreover, as illustrated by the uses of rural forests pointed out by our respondents and the many provisioning services derived from them, we argue that rural forests should not be considered unproductive areas. Better recognition of their products and services and more support in exploiting these could help farmers obtain more benefits from rural forests, which could incite them to conserve this productive asset. For example, creating supportive measures to promote regional fuel wood commodification could be one way to improve economic advantages from woodlands while meeting an increasing national demand.

Lastly, some farmers raised the issue of constant changes to CAP directives, which generates economic uncertainty. For example, they worried about the possibility of a ban on tree-felling in the future, which led them to begin removing wooded areas from their farms as a precaution. While we lack data to assess the extent of these removals, our interviews confirmed this negative result of CAP greening measures on rural forests based on farmers' perceptions of the directives and an ever-changing and unclear agenda. As other authors have argued, it seems crucial for CAP measures to be better targeted and adapted to local contexts (Jakobsson et Lindborg, 2015) and for the wider agenda to be clearer. This could be achieved, for example, by adding some flexibility regarding the expansion of hedgerows over cropland and meadows to ensure that farmers would not be afraid of reductions in direct payments if hedgerows extend into arable lands. Furthermore, if one hedgerow is registered as an EFA, it should be able to be easily substituted by another hedgerow on the farm, so that farmers can more easily adapt their farms to a changing socio-economic and environmental context. In short, the indicators used to allot CAP subsidies should better integrate two antagonistic objectives: the maintenance of rural forests and other types of EFAs that favor the ecological functioning of agricultural landscapes, and the ability of farmers to adapt their farms and practices to a changing environment.

\section{Conclusion}

Understanding how local landscape and ecosystem managers perceive, use and manage an environment and its natural resources is increasingly acknowledged as a critical step in better targeting environmental policies and improving their effectiveness. With this perspective in mind, this study aimed to assess through interviews how farmers from an agricultural region in southwestern France perceive and manage rural forests, which are key ecological features for the functioning and sustainability of agricultural landscapes. Combining qualitative and quantitative methods, the results showed that rural forests are perceived as a source of multiple ecosystem services and benefits. Furthermore, the material and non-material aspects of rural forests are often deeply intertwined. For instance, the harvesting of firewood from trees on farmland offers the means to acquire provisioning ES and to regulate tree encroachment in cropland, as well as to maintain certain social interactions such as mutual-aid networks. The results also illustrated the reality that for farmers, rural forests also represent a source of ecosystem disservices. These impacted farmers' well-being either directly (e.g. risk to their safety, damage to tractors) or indirectly by reducing certain ES (e.g. decline in yields caused by treecrop competition). Some EDS were reinforced by inadequate legislative frameworks, such as the loss of CAP subsidies if forested areas expand over cropland, which illustrates that EDS, like ES, are coproduced by human and ecological factors. The findings showed that ES and EDS were perceived differently between farmers, with EDS the main source of variability in farmers' perceptions. Hence, this study illustrates how a combination of ES and EDS can help explore the complexity of local perceptions of ecosystems and contribute to achieving a more accurate, exhaustive vision of views and attitudes. Including EDS in socio-cultural valuations of the environment is a key challenge for future research on social-ecological systems. Finally, by highlighting how global policies can be differently received by local stakeholders, we advocate for the adaptation of CAP greening measures to local realities and for a more stable $\mathrm{CAP}$ agenda to avoid farmers reacting in anticipation of potential future 
restrictions. More specifically, CAP greening measures should define indicators that target the maintenance of rural forests (i.e. a minimum area of rural forests per farm) while allowing farmers to adapt their management practices of rural forests to changing socio-economic and environmental contexts.

\section{Acknowledgements}

This work was part of the ACTAFORSE project supported by the Fondation de France and the LTSER Zone Atelier "Pyrénées-Garonne". We would also like to thank the interviewed farmers for kindly agreeing to participate in the study.

\section{References}

1. Andrieu, E., Ladet, S., Heintz, W., Deconchat, M., 2011. History and spatial complexity of deforestation and logging in small private forests. Landsc. Urban Plan. 103, 109-117. https://doi.org/10.1016/j.landurbplan.2011.06.005

2. Ango, T.G., Börjeson, L., Senbeta, F., 2016. Crop raiding by wild mammals in Ethiopia: impacts on the livelihoods of smallholders in an agriculture-forest mosaic landscape. Oryx 51, 1-11. https://doi.org/10.1017/S0030605316000028

3. Ango, T.G., Börjeson, L., Senbeta, F., Hylander, K., 2014. Balancing ecosystem services and disservices: Smallholder farmers' use and management of forest and trees in an agricultural landscape in southwestern Ethiopia. Ecol. Soc. 19. https://doi.org/10.5751/ES-06279-190130

4. Arnaiz-Schmitz, C., Herrero-Jáuregui, C., Schmitz, M.F., 2018. Losing a heritage hedgerow landscape. Biocultural diversity conservation in a changing social-ecological Mediterranean system. Sci. Total Environ. 637-638, 374-384. https://doi.org/10.1016/j.scitotenv.2018.04.413

5. Baudry, J., Bunce, R.G.., Burel, F., 2000. Hedgerows: An international perspective on their origin, function and management. J. Environ. Manage. 60, 7-22. https://doi.org/10.1006/jema.2000.0358

6. Bingham, G., Bishop, R., Brody, M., Bromley, D., Clark, E. (Toby), Cooper, W., Costanza, R., Hale, T., Hayden, G., Kellert, S., Norgaard, R., Norton, B., Payne, J., Russell, C., Suter, G., 1995. Issues in ecosystem valuation: improving information for decision making. Ecol. Econ. 14, 73-90. https://doi.org/10.1016/09218009(95)00021-Z

7. Blanco, J., Dendoncker, N., Barnaud, C., Sirami, C., 2019a. Ecosystem disservices matter: Towards their systematic integration within ecosystem service research and policy. Ecosyst. Serv. 36, 100913. https://doi.org/10.1016/j.ecoser.2019.100913

8. Blanco, J., Sourdril, A., Deconchat, M., Ladet, S., Andrieu, E., 2019b. Social drivers of rural forest dynamics: A multi-scale approach combining ethnography, geomatic and mental model analysis. Landsc. Urban Plan. 188, 132-142. https://doi.org/10.1016/j.landurbplan.2018.02.005

9. Brauman, K.A., Daily, G.C., Duarte, T.K., Mooney, H. a., 2007. The Nature and Value of Ecosystem Services: An Overview Highlighting Hydrologic Services. Annu. Rev. Environ. Resour. 32, 67-98. https://doi.org/10.1146/annurev.energy.32.031306.102758

10. Burel, F., Baudry, J., 1990. Structural dynamic of a hedgerow network landscape in Brittany France. Landsc. Ecol. 4, 197-210. https://doi.org/10.1007/BF00129828

11. Campagne, C.S., Roche, P.K., Salles, J.M., 2018. Looking into Pandora's Box: Ecosystem disservices assessment and correlations with ecosystem services. Ecosyst. Serv. 30, 126-136. https://doi.org/10.1016/j.ecoser.2018.02.005

12. Cardinale, B.J., Duffy, J.E., Gonzalez, A., Hooper, D.U., Perrings, C., Venail, P., Narwani, A., Mace, G.M., Tilman, D., A.Wardle, D., Kinzig, A.P., Daily, G.C., Loreau, M., Grace, J.B., Larigauderie, A., Srivastava, D.S., Naeem, S., 2012. Biodiversity loss and its impact on humanity. Nature 489, 326-326. https://doi.org/10.1038/nature11373

13. Choisis, J.-P.P., Sourdril, A., Deconchat, M., Balent, G., Gibon, A., 2010. Comprendre la dynamique régionale des exploitations de polyculture élevage pour accompagner le développement rural dans les Coteaux de Gascogne. Cah. Agric. 19, 97-103. https://doi.org/10.1684/agr.2010.0375

14. Chouinard, H.H., Paterson, T., Wandschneider, P.R., Ohler, A.M., 2008. Will Farmers Trade Profits for Stewardship? Heterogeneous Motivations for Farm Practice Selection. Land Econ. 84, 66-82. https://doi.org/10.3368/le.84.1.66

15. Da Ponte, E., Kuenzer, C., Parker, A., Rodas, O., Oppelt, N., Fleckenstein, M., 2017. Forest cover loss in Paraguay and perception of ecosystem services: A case study of the Upper Parana Forest. Ecosyst. Serv. 24, 
200-212. https://doi.org/10.1016/j.ecoser.2017.03.009

16. Dainese, M., Montecchiari, S., Sitzia, T., Sigura, M., Marini, L., 2017. High cover of hedgerows in the landscape supports multiple ecosystem services in Mediterranean cereal fields. J. Appl. Ecol. 54, 380-388. https://doi.org/10.1111/1365-2664.12747

17. Diniz, F.H., Kok, K., Hoogstra-Klein, M.A., Arts, B., 2015. Mapping future changes in livelihood security and environmental sustainability based on perceptions of small farmers in the Brazilian Amazon. Ecol. Soc. 20, art26. https://doi.org/10.5751/ES-07286-200226

18. Dondina, O., Kataoka, L., Orioli, V., Bani, L., 2016. How to manage hedgerows as effective ecological corridors for mammals: A two-species approach. Agric. Ecosyst. Environ. 231, 283-290. https://doi.org/10.1016/j.agee.2016.07.005

19. Dorresteijn, I., Schultner, J., Collier, N.F., Hylander, K., Senbeta, F., Fischer, J., 2017. Disaggregating ecosystem services and disservices in the cultural landscapes of southwestern Ethiopia: a study of rural perceptions. Landsc. Ecol. 32, 1-15. https://doi.org/10.1007/s10980-017-0552-5

20. Du Bus de Warnaffe, G., Deconchat, M., Ladet, S., Balent, G., 2006. Variability of cutting regimes in small private woodlots of south-western France. Ann. For. Sci. 63, 915-927. https://doi.org/10.1051/forest:2006075

21. Duru, M., Therond, O., Fares, M., 2015. Designing agroecological transitions; A review. Agron. Sustain. Dev. 35, 1237-1257. https://doi.org/10.1007/s13593-015-0318-X

22. European Commission, 2017. Report from the commission to the European parliament and the council on the implementation of the ecological focus area obligation under the green direct payment scheme. Brussels

23. Fischer, J., Abson, D.J., Butsic, V., Chappell, M.J., Ekroos, J., Hanspach, J., Kuemmerle, T., Smith, H.G., von Wehrden, H., 2014. Land sparing versus land sharing: Moving forward. Conserv. Lett. 7, 149-157. https://doi.org/10.1111/conl.12084

24. Garrido, P., Elbakidze, M., Angelstam, P., 2017. Stakeholders' perceptions on ecosystem services in Östergötland's (Sweden) threatened oak wood-pasture landscapes. Landsc. Urban Plan. 158, 96-104. https://doi.org/10.1016/j.landurbplan.2016.08.018

25. Genin, D., Aumeeruddy-Thomas, Y., Balent, G., Nasi, R., 2013. The Multiple Dimensions of Rural Forests: Lessons from a Comparative Analysis. Ecol. Soc. 18, art27. https://doi.org/10.5751/ES-05429-180127

26. Gómez-Baggethun, E., Barton, D.N., 2013. Classifying and valuing ecosystem services for urban planning. Ecol. Econ. 86, 235-245. https://doi.org/10.1016/j.ecolecon.2012.08.019

27. Haines-Young, R., Potschin, M.B., 2018. Common International Classification of Ecosystem Services (CICES) V5.1 and Guidance on the Application of the Revised Structure.

28. Hartel, T., Réti, K.-O., Craioveanu, C., 2017. Valuing scattered trees from wood-pastures by farmers in a traditional rural region of Eastern Europe. Agric. Ecosyst. Environ. 236, 304-311. https://doi.org/10.1016/j.agee.2016.11.019

29. Home, R., Balmer, O., Jahrl, I., Stolze, M., Pfiffner, L., 2014. Motivations for implementation of ecological compensation areas on swiss lowland farms. J. Rural Stud. 34, 26-36. https://doi.org/10.1016/j.jrurstud.2013.12.007

30. Husson, F., Lê, S., Pages, J., 2017. FactoMineR: Multivariate Exploratory Data Analysis and Data Mining.

31. Jakobsson, S., Lindborg, R., 2017. The importance of trees for woody pasture bird diversity and effects of the European Union's tree density policy. J. Appl. Ecol. 54, 1638-1647. https://doi.org/10.1111/13652664.12871

32. Jakobsson, S., Lindborg, R., 2015. Governing nature by numbers - EU subsidy regulations do not capture the unique values of woody pastures. Biol. Conserv. 191, 1-9. https://doi.org/10.1016/j.biocon.2015.06.007

33. La Notte, A., D’Amato, D., Mäkinen, H., Paracchini, M.L., Liquete, C., Egoh, B., Geneletti, D., Crossman, N.D., 2017. Ecosystem services classification: A systems ecology perspective of the cascade framework. Ecol. Indic. 74, 392-402. https://doi.org/10.1016/j.ecolind.2016.11.030

34. Lugnot, M., Martin, G., 2013. Biodiversity provides ecosystem services: Scientific results versus stakeholders' knowledge. Reg. Environ. Chang. 13, 1145-1155. https://doi.org/10.1007/s10113-013-0426-6

35. Lyytimäki, J., 2014. Bad nature: Newspaper representations of ecosystem disservices. Urban For. Urban Green. 13, 418-424. https://doi.org/10.1016/j.ufug.2014.04.005

36. Mackenzie, C.A., Ahabyona, P., 2012. Elephants in the garden: Financial and social costs of crop raiding. Ecol. Econ. 75, 72-82. https://doi.org/10.1016/j.ecolecon.2011.12.018

37. Manning, A.D., Fischer, J., Lindenmayer, D.B., 2006. Scattered trees are keystone structures - Implications for conservation. Biol. Conserv. 132, 311-321. https://doi.org/10.1016/j.biocon.2006.04.023

38. Martin-Lopez, B., Montes, C., Benayas, J., 2007. Influence of user characteristics on valuation of ecosystem services in Doñana Natural Protected Area (south-west Spain). Environ. Conserv. 34, 215-224. https://doi.org/10.1017/S0376892907004067

39. Oreszczyn, S., Lane, A., 2000. The meaning of hedgerows in the English landscape: Different stakeholder perspectives and the implications for future hedge management. J. Environ. Manage. 60, 101-118. 
https://doi.org/10.1006/jema.2000.0365

40. Pascua, P., McMillen, H., Ticktin, T., Vaughan, M., Winter, K.B., 2017. Beyond services: A process and framework to incorporate cultural, genealogical, place-based, and indigenous relationships in ecosystem service assessments. Ecosyst. Serv. https://doi.org/10.1016/j.ecoser.2017.03.012

41. Pe'er, G., Zinngrebe, Y., Hauck, J., Schindler, S., Dittrich, A., Zingg, S., Tscharntke, T., Oppermann, R., Sutcliffe, L.M.E., Sirami, C., Schmidt, J., Hoyer, C., Schleyer, C., Lakner, S., 2017. Adding Some Green to the Greening: Improving the EU's Ecological Focus Areas for Biodiversity and Farmers. Conserv. Lett. 10, 517-530. https://doi.org/10.1111/conl.12333

42. Pennec, F., Wencélius, J., Garine, E., Raimond, C., Bohbot, H., 2012. Flame 1.1 Free-list analysis under Microsoft Excel. User's guide.

43. Pereira, V.J., Martinho, D., 2017. Insights from over 30 years of common agricultural policy in Portugal. Outlook Agric. 46, 223-229. https://doi.org/10.1177/0030727017729896

44. Petit, S., Stuart, R.C., Gillespie, M.K., Barr, C.J., 2003. Field boundaries in Great Britain: stock and change between 1984, 1990 and 1998. J. Environ. Manage. 67, 229-238. https://doi.org/10.1016/S0301 4797(02)00176-7

45. Pfund, J.-L., Watts, J.D., Boissière, M., Boucard, A., Bullock, R.M., Ekadinata, A., Dewi, S., Feintrenie, L., Levang, P., Rantala, S., Sheil, D., Sunderland, T.C.H., Urech, Z.L., 2011. Understanding and Integrating Local Perceptions of Trees and Forests into Incentives for Sustainable Landscape Management. Environ. Manage. 48, 334-349. https://doi.org/10.1007/s00267-011-9689-1

46. QSR International Pty Ltd., s. d. NVivo version 11.4.1.1064.

47. R Core Team, 2018. R: A Language and Environment for Statistical Computing.

48. Salliou, N., Barnaud, C., 2017. Landscape and biodiversity as new resources for agro-ecology? Insights from farmers' perspectives. Ecol. Soc. 22. https://doi.org/10.5751/ES-09249-220216

49. Schmuki, R., De Blois, S., Bouchard, A., Domon, G., 2002. Spatial and Temporal Dynamics of Hedgerows in Three Agricultural Landscapes of Southern Quebec, Canada. Environ. Manage. 30, 651-664. https://doi.org/10.1007/s00267-002-2704-9

50. Sebek, P., Vodka, S., Bogusch, P., Pech, P., Tropek, R., Weiss, M., Zimova, K., Cizek, L., 2016. Opengrown trees as key habitats for arthropods in temperate woodlands: The diversity, composition, and conservation value of associated communities. For. Ecol. Manage. 380, 172-181. https://doi.org/10.1016/j.foreco.2016.08.052

51. Shackleton, C.M., Ruwanza, S., Sinasson Sanni, G.K., Bennett, S., De Lacy, P., Modipa, R., Mtati, N., Sachikonye, M., Thondhlana, G., 2016. Unpacking Pandora's Box: Understanding and Categorising Ecosystem Disservices for Environmental Management and Human Wellbeing. Ecosystems 19, 587-600. https://doi.org/10.1007/s10021-015-9952-z

52. Smith, H.F., Sullivan, C.A., 2014. Ecosystem services within agricultural landscapes-Farmers' perceptions. Ecol. Econ. 98, 72-80. https://doi.org/10.1016/j.ecolecon.2013.12.008

53. Sourdril, A., 2008. Territoire et hiérarchie dans une société à maison Bas-Commingeoise: Permanence et changement. Des bois, des champs, des près (Haute-Garonne). Université de Paris X - Nanterre.

54. Sourdril, A., Andrieu, E., Cabanettes, A., Elyakime, B., Ladet, S., 2012. How to Maintain Domesticity of Usages in Small Rural Forests? Lessons from Forest Management Continuity through a French Case Study. Ecol. Soc. 17, art6. https://doi.org/10.5751/ES-04746-170206

55. Spangenberg, J.H., Görg, C., Truong, D.T., Tekken, V., Bustamante, J.V., Settele, J., 2014. Provision of ecosystem services is determined by human agency, not ecosystem functions. Four case studies. Int. J. Biodivers. Sci. Ecosyst. Serv. Manag. 10, 40-53. https://doi.org/10.1080/21513732.2014.884166

56. Tadaki, M., Sinner, J., Chan, K.M.A., 2017. Making sense of environmental values: a typology of concepts. Ecol. Soc. 22, art7. https://doi.org/10.5751/ES-08999-220107

57. Teixeira, F.Z., Bachi, L., Blanco, J., Zimmermann, I., Welle, I., Carvalho-Ribeiro, S.M., 2019. Perceived ecosystem services (ES) and ecosystem disservices (EDS) from trees: insights from three case studies in Brazil and France. Landsc. Ecol. 34, 1583-1600. https://doi.org/10.1007/s10980-019-00778-y

58. Torralba, M., Fagerholm, N., Burgess, P.J., Moreno, G., Plieninger, T., 2016. Do European agroforestry systems enhance biodiversity and ecosystem services? A meta-analysis. Agric. Ecosyst. Environ. 230, 150-161. https://doi.org/10.1016/j.agee.2016.06.002

59. Van Vooren, L., Reubens, B., Broekxx, S., De Frenne, P., Nelissen, V., Pardon, P., Verheyen, K., 2017. Ecosystem service delivery of agri-environment measures: A synthesis for hedgerows and grass strips on arable land. Agric. Ecosyst. Environ. 244, 32-51. https://doi.org/10.1016/j.agee.2017.04.015

60. Vanclay, F., 2004. Social principles for agricultural extension to assist in the promotion of natural resource management. Aust. J. Exp. Agric. 44, 213. https://doi.org/10.1071/EA02139 


\section{Supplementary material 1}

Table S1: Main characteristics of the farms located in the Canton of Aurignac in 1988 and in 2010 according to data from the French agricultural statistics and assessment service (available at http://recensement-agricole.agriculture.gouv.fr/)

\begin{tabular}{|c|c|c|c|c|c|}
\hline \multirow{2}{*}{\multicolumn{2}{|c|}{ Year }} & \multicolumn{2}{|c|}{$\begin{array}{c}\text { In number } \\
\text { (and percentages of the total) }\end{array}$} & \multicolumn{2}{|c|}{$\begin{array}{c}\text { In surface area (ha) } \\
\text { (and percentages of the total) }\end{array}$} \\
\hline & & 1988 & 2010 & 1988 & 2010 \\
\hline \multicolumn{6}{|c|}{ Types of farming systems } \\
\hline- & Crop systems & $41(11 \%)$ & $79(35 \%)$ & $1,321(11 \%)$ & $2,866(35 \%)$ \\
\hline- & Mixed farming systems & $183(47 \%)$ & $47(21 \%)$ & $5,374(43 \%)$ & $3,332(27 \%)$ \\
\hline- & Cattle-based systems & $114(29 \%)$ & $59(26 \%)$ & $4,068(33 \%)$ & $3,788(31 \%)$ \\
\hline- & Other & $52(13 \%)$ & $40(18 \%)$ & $1,597(13 \%)$ & $753(7 \%)$ \\
\hline \multicolumn{2}{|c|}{ Total } & 390 & 225 & 12,360 & 10,739 \\
\hline \multicolumn{6}{|c|}{ Farmers' age } \\
\hline- & $<40$ year-old & $79(20 \%)$ & $42(19 \%)$ & $3,120(25 \%)$ & $3,291(30 \%)$ \\
\hline- & 40-50 year-old & $73(19 \%)$ & $45(20 \%)$ & $2,760(22 \%)$ & $2,127(20 \%)$ \\
\hline- & 50-60 year-old & $113(29 \%)$ & $74(33 \%)$ & $3,536(29 \%)$ & $4,245(40 \%)$ \\
\hline- & $>60$ year-old & $125(32 \%)$ & $64(28 \%)$ & $2,944(24 \%)$ & $1,075(10 \%)$ \\
\hline \multicolumn{2}{|c|}{ Total } & 390 & 225 & 12,360 & 10,739 \\
\hline
\end{tabular}


Table S2: Main characteristics of the 19 interviewed farmers, of their farm and woodland estate, and total number of rural forest positive (FPC) and negative contributions (FNC) identified from interviews.

\begin{tabular}{|c|c|c|c|c|c|c|c|c|c|}
\hline Farmer & Age & Gender & Farming system & $\begin{array}{c}\text { Farm surface } \\
\text { area* (ha) }\end{array}$ & $\begin{array}{c}\text { No of } \\
\text { blocks }\end{array}$ & $\begin{array}{c}\text { No of } \\
\text { woodlots }\end{array}$ & $\begin{array}{l}\text { Woodlot total } \\
\text { area (ha) }\end{array}$ & $\begin{array}{l}\text { No of } \\
\text { FPCs }\end{array}$ & $\begin{array}{l}\text { No of } \\
\text { FNCs }\end{array}$ \\
\hline F01 & 59 & $\mathrm{~F}$ & $\begin{array}{l}\text { Organic crop } \\
\text { system }\end{array}$ & 13.4 & 2 & 0 & 0.00 & 8 & 3 \\
\hline F02 & 66 & M & $\begin{array}{l}\text { Organic crop } \\
\text { system }\end{array}$ & 61.3 & 5 & 1 & 0.82 & 8 & 2 \\
\hline F03 & 54 & M & $\begin{array}{l}\text { Conventional mix } \\
\text { farming }\end{array}$ & 129.0 & 14 & 10 & 11.00 & 9 & 3 \\
\hline F04 & 68 & M & $\begin{array}{l}\text { Conventional crop } \\
\text { system }\end{array}$ & 114.8 & 15 & 1 & 1.92 & 7 & 2 \\
\hline F05 & 39 & M & $\begin{array}{l}\text { Conventional } \\
\text { mixed farming }\end{array}$ & 139.5 & 23 & 5 & 9.85 & 7 & 4 \\
\hline F06 & 55 & M & $\begin{array}{l}\text { Conventional } \\
\text { mixed farming }\end{array}$ & 123.5 & 19 & 4 & 4.73 & 8 & 4 \\
\hline F07 & 45 & M & $\begin{array}{l}\text { Conventional } \\
\text { mixed farming }\end{array}$ & 110.3 & 17 & 4 & 4.20 & 7 & 3 \\
\hline F08 & 52 & M & $\begin{array}{c}\text { Conventional crop } \\
\text { system }\end{array}$ & 248.7 & 40 & 3 & 1.13 & 10 & 6 \\
\hline F09 & NA & M & $\begin{array}{l}\text { Conventional } \\
\text { mixed farming }\end{array}$ & 108.8 & 9 & 5 & 5.42 & 7 & 4 \\
\hline F10 & NA & M & $\begin{array}{c}\text { Conventional crop } \\
\text { system }\end{array}$ & 72.2 & 9 & 3 & 12.01 & 7 & 2 \\
\hline F11 & 31 & $\mathrm{~F}$ & $\begin{array}{l}\text { Conventional crop } \\
\text { system }\end{array}$ & 38.6 & 8 & 2 & 0.40 & 6 & 3 \\
\hline F12 & 58 & M & $\begin{array}{l}\text { Conventional } \\
\text { mixed farming }\end{array}$ & 94.4 & 15 & 3 & 3.13 & 4 & 4 \\
\hline F13 & 43 & M & $\begin{array}{l}\text { Organic crop } \\
\text { system }\end{array}$ & 24.8 & 3 & 3 & 3.91 & 10 & 2 \\
\hline F14 & 60 & $\mathrm{M}$ & $\begin{array}{l}\text { Conventional } \\
\text { mixed farming }\end{array}$ & 121.8 & 31 & 2 & 1.15 & 7 & 2 \\
\hline F15 & 63 & $\mathrm{M}$ & $\begin{array}{c}\text { Conventional crop } \\
\text { system }\end{array}$ & 51.2 & 10 & 0 & 0.00 & 4 & 3 \\
\hline F16 & 40 & $\mathrm{M}$ & $\begin{array}{l}\text { Conventional } \\
\text { mixed farming }\end{array}$ & 165.2 & 12 & 5 & 6.80 & 9 & 4 \\
\hline F17 & 36 & $\mathrm{M}$ & $\begin{array}{c}\text { Conventional crop } \\
\text { system }\end{array}$ & 103.2 & 19 & 1 & 0.39 & 7 & 4 \\
\hline F18 & 50 & M & $\begin{array}{l}\text { Conventional } \\
\text { mixed farming }\end{array}$ & 250.8 & 42 & 5 & 5.89 & 6 & 2 \\
\hline F19 & 48 & $\mathrm{M}$ & $\begin{array}{l}\text { Conventional } \\
\text { mixed farming }\end{array}$ & 152.7 & 22 & 2 & 4.60 & 8 & 4 \\
\hline Total & & & & 2124.2 & 315 & 59 & 77.36 & 32 & 25 \\
\hline
\end{tabular}

* Farm surface area was assessed from the 2014 version of the RPG, which is the French version of the European Land Parcel Identification System (LPIS).

II Blocks are the geographical entities in the RPG data, defined as one or several contiguous agricultural plots managed by the same farmer. 
Table S3: List of the 32 "Rural Forest Positive Contributions" (FPC) and corresponding "advantages" (in French and in English) cited by farmers during interviews.

\begin{tabular}{|c|c|c|c|}
\hline $\begin{array}{l}\text { Rural Forest Positive } \\
\text { Contributions (FPC) } \\
\end{array}$ & $\begin{array}{c}\text { Corresponding advantage } \\
\text { (French) }\end{array}$ & $\begin{array}{c}\text { Corresponding advantage } \\
\text { (English) }\end{array}$ & Farmers \\
\hline \multirow[t]{2}{*}{ Firewood (P1) } & Bois de chauffage & Firewood & $\begin{array}{l}\text { F01, F02, F03, } \\
\text { F04, F06, F07, } \\
\text { F08, F09, F12, } \\
\text { F13, F14, F15, } \\
\text { F16, F17, F18, } \\
\text { F19 }\end{array}$ \\
\hline & $\begin{array}{l}\text { Economies sur les dépenses } \\
\text { d'énergie }\end{array}$ & Savings on energy expenses & F10 \\
\hline \multirow{5}{*}{ Fruits \& nuts (P2) } & Fruits (au moins les voir) & Fruits (seeing them at least) & F01, F07 \\
\hline & Noix & Walnuts & F02, F18 \\
\hline & Manger des cerises & Eat cherries & F04 \\
\hline & Nourriture & Food & F08 \\
\hline & Fruits & Fruits & $\begin{array}{l}\text { F09, F12, F13, } \\
\text { F14, F16 }\end{array}$ \\
\hline Medicinal plants (P3) & Plantes médicinales & Medicinal plants & F13 \\
\hline \multirow[t]{2}{*}{ Mushrooms (P4) } & Champignons & Mushrooms & $\begin{array}{l}\text { F03, F05, F06, } \\
\text { F08, F09, F13, } \\
\text { F16, F18, F19 }\end{array}$ \\
\hline & Cèpes & Ceps & F17 \\
\hline \multirow{3}{*}{ Habitat for game (P5) } & Abri pour le gibier & Shelter for game & F02, F03 \\
\hline & Refuge pour gibier & Refuge for game & F05 \\
\hline & Gibier & Game & F08 \\
\hline \multirow{3}{*}{ Wood \& timber (P6) } & Bois d'œuvre & Timber & F04, F06, F07 \\
\hline & Bois de construction & Timber & F16 \\
\hline & Grumes & Timber logs & F03 \\
\hline \multirow{2}{*}{ Picket fence (P7) } & Piquets & Pickets & F09 \\
\hline & Piquets d'acacia & Pickets in acacia wood & F17 \\
\hline $\begin{array}{l}\text { Pastoral areas \& } \\
\text { resources }(\mathrm{P} 8)\end{array}$ & Pacage & Grazing & F05 \\
\hline \multirow{3}{*}{$\begin{array}{l}\text { Shade \& fresh air for } \\
\text { humans }(\mathrm{R} 1)\end{array}$} & Ombrage & Shade & F01, F02 \\
\hline & Ombre quand il fait chaud & Shade when the weather is hot & F04, F08 \\
\hline & $\begin{array}{l}\text { Ombre pour les hommes et } \\
\text { tracteurs }\end{array}$ & Shade for humans and tractors & F15 \\
\hline \multirow{6}{*}{$\begin{array}{l}\text { Oxygen production } \\
\text { and air quality (R2) }\end{array}$} & Fraîcheur & Fresh air & F04 \\
\hline & Rend de l'O2 & Produce oxygen & F04 \\
\hline & Qualité de l'air & Air quality & F06, F17 \\
\hline & Pour l'oxygène & For oxygen & F08 \\
\hline & Production d'oxygène & Oxygen production & F14 \\
\hline & Oxygène & Oxygen & F15 \\
\hline \multirow{3}{*}{$\begin{array}{l}\text { Shade for reared } \\
\text { animals (R3) }\end{array}$} & Ombre pour les vaches & Shelter for cows & F06 \\
\hline & Fraîcheur l'été (vaches) & $\begin{array}{l}\text { Fresh air during summer (for } \\
\text { cows) }\end{array}$ & F07 \\
\hline & Ombre pour les animaux & Shade for animals & F16, F19 \\
\hline \multirow{4}{*}{$\begin{array}{l}\text { Gully \& erosion } \\
\text { control (R4) }\end{array}$} & Evite le ravinement & Avoid gully & F01 \\
\hline & Tient la terre & Keep soils still & F02 \\
\hline & Erosion & Erosion & F03, F06, F14 \\
\hline & Erosion des fossés et talus & $\begin{array}{l}\text { (Regulate) erosion of ditches } \\
\text { and banks }\end{array}$ & F05 \\
\hline
\end{tabular}


Tient les berges

Tenue des digues

Limite l'érosion

Tenir le talus

Tenir le talus des ruisseaux

Tient la bordure des fossés et talus Contre l'érosion

Abri pour les volatiles (sauvages)

Abri pour les oiseaux (palombes)

Habitat for wild birds (R5)

Habitat for insects
(R6)

Abri pour la faune sauvage

Vie de l'écosystème (oiseaux)

Bénéfique pour les oiseaux

Equilibre pour les cultures

Refuge pour la biodiversité

Refuge pollinisateurs

Abri à insectes

Abri pour les volatiles

(domestiques)

Abri pour les vaches

Abri naturel pour les animaux

Shelter for reared Protège les animaux du vent animals (R7)

Abri pour les vaches (orage)

Coupe le vent pour les vaches

Abri pour les bêtes

Protection pour l'élevage

Couper le vent (céréales)

Abri du vent

Windbreak effect for crops (R8)

Brise-vent

Protection naturelle des cultures

Coupe le vent des cultures

Effet brise-vent

\begin{tabular}{cl} 
& Effet brise-vent \\
\hline $\begin{array}{c}\text { Slow down water } \\
\text { flows (R9) }\end{array}$ & Ralenti l'écoulement \\
Ralenti l'eau
\end{tabular}

\begin{tabular}{cl}
\hline $\begin{array}{c}\text { Humus production } \\
(\mathrm{R} 10)\end{array}$ & Humus des feuilles \\
\hline Soil aeration (R11) & Racines aèrent le sol \\
\hline $\begin{array}{c}\text { Remove nitrates and } \\
\text { other chemicals (R12) }\end{array}$ & Collecteur de nitrates \\
\hline $\begin{array}{c}\text { Fill gaps in the visual } \\
\text { landscape (R13) }\end{array}$ & Coupe le vide visuel \\
\hline
\end{tabular}

Beauté

Esthétique

Paysage (visuel)

Landscape scenic (C1)

côté visuel

Paysage (esthétique)

Aspect visuel

Maintien du paysage

Décoration/ beau
Keep banks still F06

Keep banks still

F08

Regulate erosion

F09, F10

Holding banks

F12

Holding banks along water streams

F17

Hold ditches and banks

F18

Against erosion

F19

Shelter for volatiles (wild)

F01

Shelter for birds (pigeons)

F02

Shelter for fauna

F03

Life of ecosystems (birds)

F13

Positive to birds

F14

Maintain a balance for crops

F03

Refuge for biodiversity

F04

Refuge for pollinators

F05

Shelter for insects

F11

Shelter for volatiles (domestic)

F01

Shelter for cows

F05, F11

Natural shelter for animals

F09

Protect animals from wind

F09

Shelter for cows (during

storms)

F12

Windbreak for cows

F14

Shelter for animals

F18

Protection for rearing

F17

Windbreak (cereals)

F03

Protect from wind

F08

Windbreak

F11

Natural protection of crops

F13

Windbreak for crops

F14

Windbreak effect

F16

Slow down water flows

F08

Slow down water flows

F09

Humus from leaves

F11

Roots allow soil aeration

F11

Collect nitrates

F11

Fill visual gaps

F19

Beauty

F01

Esthetics

F02

Landscape (visual experience)

F03

Visual aspect

F04

Landscape (esthetics)

F06

Visual aspect

F07

Landscape maintenance

F10

Beautiful

F13 


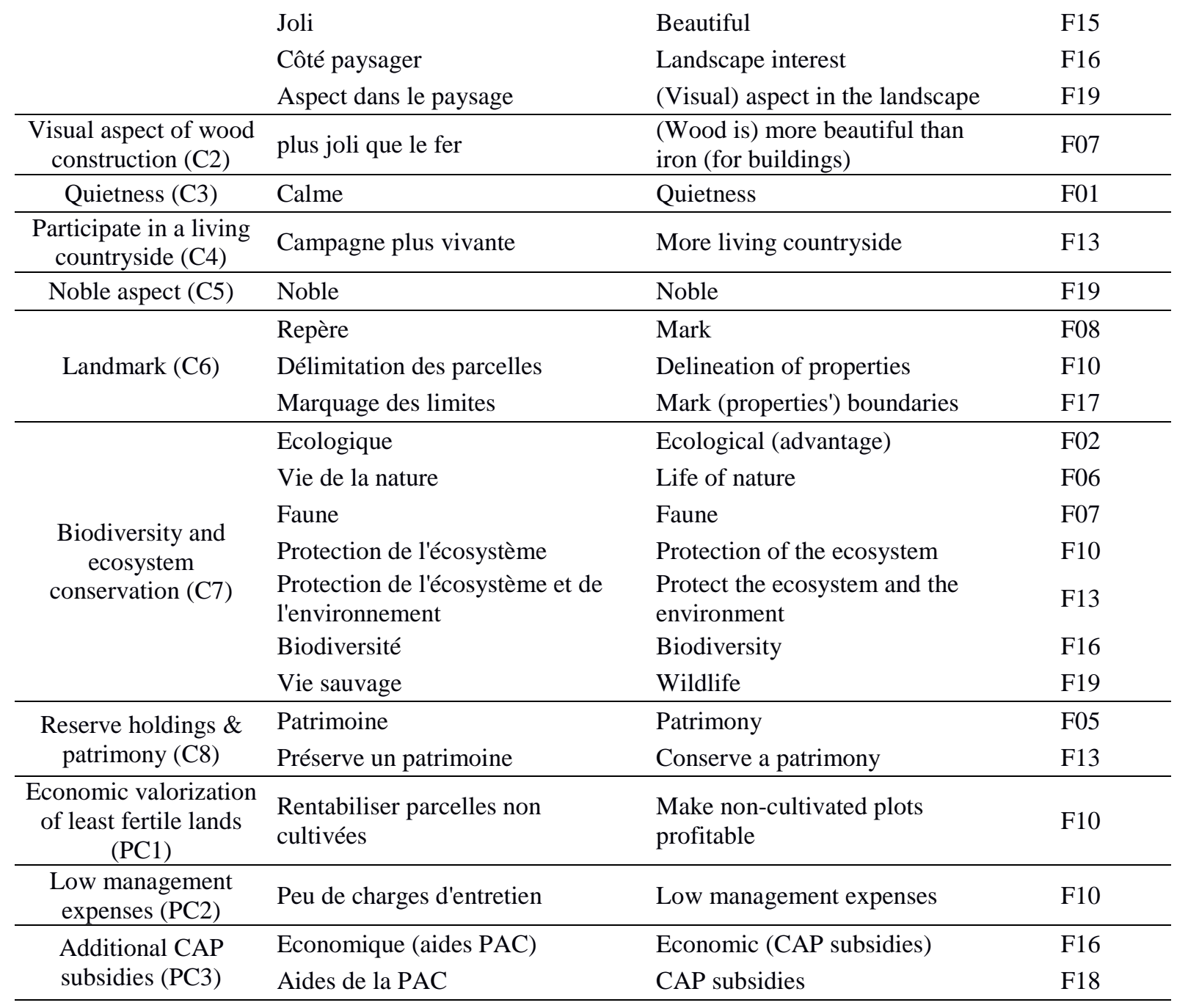


Table S4: List of the 25 'Rural Forest Negative Contributions' (FNC) and corresponding 'disadvantages' (in French and in English) cited by farmers during interviews.

\begin{tabular}{|c|c|c|c|}
\hline $\begin{array}{l}\text { Rural Forest Negative } \\
\text { Contributions (FNC) }\end{array}$ & $\begin{array}{l}\text { Corresponding disadvantage } \\
\text { (French) }\end{array}$ & $\begin{array}{c}\text { Corresponding disadvantage } \\
\text { (English) }\end{array}$ & $\begin{array}{c}\text { Far } \\
\text { mers }\end{array}$ \\
\hline \multirow{8}{*}{ Branches damage tractors (MD1) } & Casse les rétroviseurs & Break side mirrors & F01 \\
\hline & Dommage au matériel & Damages on material & F01 \\
\hline & Repousses de branches (tracteur) & $\begin{array}{l}\text { Branches grow (issue for } \\
\text { tractors) }\end{array}$ & F02 \\
\hline & $\begin{array}{l}\text { Branches abîment le matériel } \\
\text { agricole }\end{array}$ & $\begin{array}{l}\text { Branches damage agricultural } \\
\text { equipment }\end{array}$ & F05 \\
\hline & $\begin{array}{l}\text { Dégâts sur les machines par les } \\
\text { branches }\end{array}$ & $\begin{array}{l}\text { Damages on machines caused } \\
\text { by branches }\end{array}$ & F06 \\
\hline & $\begin{array}{l}\text { Abîme les machines si pas } \\
\text { entretenu }\end{array}$ & $\begin{array}{l}\text { Damage machines if not } \\
\text { properly managed }\end{array}$ & F14 \\
\hline & $\begin{array}{l}\text { Abîme les cabines et les } \\
\text { rétroviseurs des tracteurs }\end{array}$ & $\begin{array}{l}\text { Damage tractors' cabins and } \\
\text { side mirrors }\end{array}$ & F18 \\
\hline & Abîme les cabines & Damage tractors' cabins & F19 \\
\hline \multirow{2}{*}{ Risks for fences (MD2) } & Risque de rupture sur les clôtures & Risk to break fences & F16 \\
\hline & Entretien pour les clôtures & Need to be managed for fences & F19 \\
\hline Risks for buildings (MD3) & Danger pour les bâtiments & Danger to buildings & F12 \\
\hline Roots damage buildings (MD4) & Racines gênent les bâtiments & Roots may damage buildings & F12 \\
\hline \multirow{4}{*}{$\begin{array}{l}\text { Roots obstruct ditches and drains } \\
\text { (MD5) }\end{array}$} & Empêche entretient des ruisseaux & $\begin{array}{l}\text { Obstruct water stream } \\
\text { management }\end{array}$ & F07 \\
\hline & Bouche les fossés & Obstruct ditches & F15 \\
\hline & $\begin{array}{l}\text { Bouchage des drains dans les } \\
\text { fossés }\end{array}$ & Obstruct drains inside ditches & F16 \\
\hline & Dégâts sur la digue & Damage riverbanks & F17 \\
\hline \multirow{2}{*}{ Expensive management (MD6) } & Coût de l'entretien & Management cost & F08 \\
\hline & Coût & Overall cost & F09 \\
\hline Low economic profitability (MD7) & Faible rentabilité & Low profitability & F10 \\
\hline \multirow{10}{*}{ Hinder work with machines (AD1) } & Gêne aux manœuvres & Hinder maneuvers & $\begin{array}{l}\text { F01, } \\
\text { F13, } \\
\text { F16 }\end{array}$ \\
\hline & Gêne le passage & Hinder the way & F02 \\
\hline & Gêne pour la mécanisation & Hinder field mechanization & $\begin{array}{l}\text { F03, } \\
\text { F04 }\end{array}$ \\
\hline & Gêne par les branches & Hindering effect of branches & F07 \\
\hline & Contournement avec les engins & Machines have to avoid them & F09 \\
\hline & $\begin{array}{l}\text { Obstacle pour le travail des } \\
\text { champs }\end{array}$ & Obstacle to working in fields & F10 \\
\hline & Gêne si pas entretenu & Hinder if not properly managed & F14 \\
\hline & Salissement (empêche l'accès) & $\begin{array}{l}\text { Mess the place (preventing the } \\
\text { access) }\end{array}$ & F17 \\
\hline & Gêne pour le travail & Hinder working (in the field) & F18 \\
\hline & Gêne selon là où elles sont & $\begin{array}{l}\text { May hinder work (according to } \\
\text { their location) }\end{array}$ & F19 \\
\hline $\begin{array}{l}\text { Low accessibility in wet periods } \\
\text { (AD2) }\end{array}$ & Trop d'humidité à l'automne & Too moist during fall season & F15 \\
\hline \multirow{3}{*}{ Additional workload (AD3) } & Beaucoup de travail & A lot of work & F03 \\
\hline & Regagne le champ & $\begin{array}{l}\text { Spread to fields (if not } \\
\text { managed) }\end{array}$ & F06 \\
\hline & Travail & Workload & $\begin{array}{l}\text { F08, } \\
\text { F17 }\end{array}$ \\
\hline
\end{tabular}




\begin{tabular}{|c|c|c|c|}
\hline & Travail en entretien & A lot of work for managing & $\begin{array}{l}\text { F15, } \\
\text { F16 }\end{array}$ \\
\hline \multirow{2}{*}{ Habitat for pests (AD4) } & Abri pour les ravageurs & Habitat for pests & F10 \\
\hline & Amène quelques nuisibles & Bring some pests & F11 \\
\hline \multirow{3}{*}{$\begin{array}{l}\text { Overall competition causing yield } \\
\text { loss (AD5) }\end{array}$} & Moins de rendement & Reduced yields & F07 \\
\hline & $\begin{array}{l}\text { Empêche développement des } \\
\text { cultures }\end{array}$ & Undermine crop growth & $\begin{array}{l}\text { F09, } \\
\text { F12 }\end{array}$ \\
\hline & Rien ne pousse dessous & Nothing grows below & F11 \\
\hline \multirow{3}{*}{ Local root competition (AD6) } & $\begin{array}{l}\text { Nuisance possible pousse des } \\
\text { céréales }\end{array}$ & Potential harm for crop growth & F04 \\
\hline & Prend de l'eau sur les cultures & Take water from crops & F08 \\
\hline & Perte de rendement pendant l'été & Yield loss in summer & F18 \\
\hline Rainfall interception (AD7) & Moins d'eau pour les cultures & Less water available for crops & F06 \\
\hline Light interception (AD8) & Ombre sur les cultures & $\begin{array}{l}\text { Produce shade on cropped } \\
\text { areas }\end{array}$ & $\begin{array}{l}\text { F06, } \\
\text { F08, } \\
\text { F17 }\end{array}$ \\
\hline \multirow{3}{*}{ Risks for reared animals (AD9) } & Gestion pour l'entretien & $\begin{array}{l}\text { Required management (for } \\
\text { mitigating risks to animals) }\end{array}$ & F05 \\
\hline & Problème de sécurité (tempêtes) & $\begin{array}{l}\text { Security issues (in case of } \\
\text { storms) }\end{array}$ & F08 \\
\hline & Danger pour les vaches & Danger to cows & F12 \\
\hline $\begin{array}{l}\text { Occupy surfaces that could be } \\
\text { better valorized (AD10) }\end{array}$ & Surfaces cultivables en moins & Reduce cropped areas & F05 \\
\hline $\begin{array}{l}\text { Habitat for the pine processionary } \\
\text { (HD1) }\end{array}$ & Chenilles processionnaires & Pine processionary & F01 \\
\hline Habitat for hornets (HD2) & Nids de frolons & Hornet nests & F04 \\
\hline \multirow{2}{*}{$\begin{array}{l}\text { Risks and inconvenience of leaf } \\
\text { falls (HD3) }\end{array}$} & Feuilles & Dead leaves & F02 \\
\hline & Feuilles (Sali) & Leaves (mess the place) & F07 \\
\hline Mandatory regulation (NC1) & $\begin{array}{l}\text { Règlementation trop } \\
\text { contraignante }\end{array}$ & Regulation too restrictive & F05 \\
\hline $\begin{array}{l}\text { Uncertainties on future changes in } \\
\text { regulations (NC2) }\end{array}$ & Evolution de la règlementation & Regulation changes & F09 \\
\hline $\begin{array}{c}\text { Fewer areas eligible for CAP } \\
\text { subsidies (NC3) }\end{array}$ & Superficie déduite de la PAC & Areas excluded from CAP & F11 \\
\hline $\begin{array}{l}\text { People do not understand farmers' } \\
\text { need to cut down trees (NC4) }\end{array}$ & $\begin{array}{l}\text { Les gens ne comprennent pas } \\
\text { qu'on coupe }\end{array}$ & $\begin{array}{l}\text { People do not understand we } \\
\text { cut (trees down) }\end{array}$ & F19 \\
\hline
\end{tabular}




\section{Supplementary material 2: detailed interview guideline}

Interviewer(s):

Date:

\section{General individual information}

Last name: Age: Id:

First name: $\quad$ Sex: $\square \mathrm{M} \quad \square \mathrm{F}$

Postal address:

Phone: (home) (cellphone)

No of children (and age):

Education:

Additional job: $\square$ No $\quad \square$ Yes, specify (job name, no of hours per week/month):

\section{Information about the farm}

Farming system: Organic/conventional:

Legislative status: No of work labor:

Surface area:

\begin{tabular}{|l|l|l|}
\hline & $2015-2016$ & $\mathbf{2 0 1 6 - 2 0 1 7}$ \\
\hline Surface area for crops & & \\
\hline Surface area for temporary meadows & & \\
\hline Surface area for permanent meadows & & \\
\hline $\begin{array}{l}\text { Livestock } \\
\text { (No of head, type of production) }\end{array}$ & & \\
& & \\
\hline
\end{tabular}




\section{Discussion about the farm and rural forests}

On the basis of an aerial photograph of the farm and its surroundings, conduct an open-ended discussion with the farmer about the farm and rural forests.

- Point different agricultural plots and ask information about land use, ownership, slope, etc.

Focus on the information that has a link with farm trees or forests and ask further details.

Examples: if the farmer cites a problem related to erosion, ask what types of measures have been taken to mitigate this problem, ask if hedgerows or other types of forested areas are effective to mitigate it, etc.

- Point different farm trees (e.g. scattered trees, hedgerows, riverbanks) and ask information about ownership, advantages and disadvantages, management practices

Focus on the terms used by farmers to name the different types of forested areas, and fill the "Spontaneous identification" column of the following table. Keep track on the cited advantages and disadvantages. Ask about the stakeholders who intervene in the management.

- Ask about forest plots and their management: locate each woodlot owned by the farmer on the map, ask information about how it is managed.

Focus on most common forest products (firewood, timber, mushrooms) and ask for other types of advantages and disadvantages. Ask information about the stakeholders who intervenes to harvest firewood and timber.

Notes: 


\section{Perceptions about rural forests}

1) Types of forested areas present on the farm

Notice:

- Spontaneous identification: from the information formerly obtained

- Co-construct typology and definition: from the spontaneous identification, discuss with the informant the differences between the different types of forested areas in order to reach an agreement on the different type of forested areas and how to distinguish them from one another.

\begin{tabular}{|c|c|c|}
\hline $\begin{array}{r}\text { Spontaneous } \\
\text { identification }\end{array}$ & Co-construct typology & Definition / Main characteristics \\
\hline $1-$ & $1-$ & $1-$ \\
\hline $2-$ & $2-$ & $2-$ \\
\hline $3-$ & $3-$ & $3-$ \\
\hline $4-$ & $4-$ & $4-$ \\
\hline $5-$ & $5-$ & $5-$ \\
\hline
\end{tabular}

2) Identification of the main stakeholders, advantages and disadvantages associated with rural forests

Notice:

- Stakeholders: Ask the informant for a synthesis of the main stakeholders intervening in the management of rural forests or influencing him/her in the management of rural forests.

- Advantages: Ask the informant for a synthesis on the main advantages, benefits and positive outcomes that are important to them associated with rural forests.

- Disadvantages: Ask the informant for a synthesis of the main disadvantages, constraints and negative outcomes that are important to them associated with rural forests.

\begin{tabular}{|l|l|l|}
\hline \multicolumn{1}{|c|}{ Stakeholders } & \multicolumn{1}{|c|}{ Advantages } & \multicolumn{1}{c|}{ Disadvantages } \\
\hline $1-$ & $1-$ & $1-$ \\
$2-$ & $2-$ & $2-$ \\
$3-$ & $3-$ & $3-$ \\
$4-$ & $4-$ & $4-$ \\
$5-$ & $5-$ & $5-$ \\
& & \\
& & \\
\hline
\end{tabular}

Notes: 
3) Mental model about rural forest management

On stickers, report the following items:

- The different types of forested areas co-construct with the farmer

- The different advantages and disadvantages cited

- The different stakeholders

With the use of the black board, co-construct a mental model with the farmer highlighting the links between: (i) Stakeholders and forested areas; and (ii) forested areas and disadvantages and advantages

Make a final oral synthesis of the mental model and ask for potential missing information or input.

Notes: 


\section{Use of firewood}

No of houses heated with the firewood from the farm:

Total no of people :

\begin{tabular}{|l|l|l|l|}
\hline Houses & Heating system & $\begin{array}{c}\text { Annual quantity of firewood and } \\
\text { other energy sources }\end{array}$ & $\begin{array}{c}\text { \% of firewood coming from } \\
\text { farm trees and from forests }\end{array}$ \\
\hline & & & \\
\hline & & & \\
\hline & & & \\
& & & \\
\hline
\end{tabular}

Main tree species used for firewood:

\begin{tabular}{|l|l|l|l|}
\hline French name & Local name & $\begin{array}{c}\text { Origin (farm } \\
\text { tree/forest tree) }\end{array}$ & $\begin{array}{c}\text { Overall quality } \\
\text { (from 0 to 10) }\end{array}$ \\
\hline & & & \\
& & & \\
& & & \\
& & & \\
\hline
\end{tabular}

Do you sell firewood? $\quad \square$ Yes $\quad \square$ No

\begin{tabular}{|c|c|c|c|c|}
\hline Tree species & $\begin{array}{c}\text { Origin (farm } \\
\text { tree/forest } \\
\text { tree) }\end{array}$ & $\begin{array}{c}\text { Annual } \\
\text { quantity sold } \\
\left(\mathbf{m}^{3}\right)\end{array}$ & $\begin{array}{c}\text { Price } \\
\left(€ / \mathbf{m}^{3}\right)\end{array}$ & $\begin{array}{c}\text { Customers (type of people, } \\
\text { place of residence) }\end{array}$ \\
\hline & & & & \\
& & & & \\
\hline
\end{tabular}




\section{Supplementary material 3: Multiple Correspondences Analyses (MCA)}

This document exposes the main analytical steps followed to conduct MCA on the basis of rural forest positive and negative contributions (FPC and FNC) cited by the 19 farmers of our study.

A total of four MCAs were performed to explore variability in farmers' perceptions. For each MCA, we present (i) the dataset used, (ii) the active and supplementary variables that are considered by the MCA, and (iii) the main results.

Results are presented through a short text and 4 figures:

- The "MCA factor map" is the plot of the farmers in the first two dimensions of the MCA (farmers are colored according to farming systems);

- The "graph of the variables" is the plot of the active variables in the first two dimensions of the MCA and highlights 20 most contributing variables;

- The "Supplementary variables on the MCA factor map" is the circle of correlations between supplementary quantitative variables and the MCA two first dimensions. These variables include (for each farmer) the farm surface area (FarmArea), the number of agricultural blocks (Blocks), the number of woodlots (Woods), the total area of woodlots (WoodArea), the farmers' age (Age), the number of FPCs cited during the interview (PCtot) and the number of FNCs cited during the interview (NCtot);

- The eigenvalue screeplot.

In addition, a table highlights the main contributions and correlations observed in the MCA:

- Individuals with $\operatorname{Cos} 2>0.5$, which indicates a significant quality of representation of these individuals in the construction of a given MCA axis;

- Active variables with eta2>0.5, which indicates a significant contribution of these variables in the construction of a given MCA axis; eta2 represents the square of the correlation ratio between each variable and each axis;

- Supplementary qualitative variables with eta2>0.5, which indicates a significant qualitative correlation between these variables and the corresponding MCA axis;

- Supplementary quantitative variables with cor $>0.3$ or $\cos <-3$, which indicates a positive or negative correlation between these variables and the corresponding MCA axis.

Finally, we explain in this document what motivated each MCA. Only the MCA N ${ }^{\circ} 4$ was presented in the main article as it was considered as the most robust for the following reasons:

- The eigenvalue screeplot shows a net gap after the first two dimensions;

- The analysis is based on a more limited number of variables (due to a low number of observations) than for the other analyses;

- The most rarely cited FPC and FNC are not included to limit issues due to the sensitivity of MCA to rare items. 


\section{MCA based on all the FPC and FNC cited by farmers}

\section{Dataset 1:}

A first MCA was performed on the basis of all the FPCs and FNCs cited by farmers. The dataset used was composed with 19 rows (one row for one farmer) considered as 19 observations. Each farmer was characterized by a set of 66 variables, including:

- 57 active variables: these variables corresponded to the 57 FPCs and FNCs identified in this study from the advantages and disadvantages cited by farmers (Table S2 and S3, Suppl. material $\mathrm{N}^{\circ} 2$ ). For the farmer $i$ and the variable $j$, the cell $[\mathrm{i}, \mathrm{j}]$ received the value " 1 " if the farmer $i$ cited the FPC (or FNC) corresponding to the variable $j$, and " 0 " otherwise.

- 9 supplementary variables that corresponded to (i) socio-economic characteristics of the farmer and its farm (farmer's age and gender, size of the farm, type of farming system, size of the forest estate) and (ii) two quantitative indicators associated with his/her perceptions (the number of FPCs he/she cited during interviews, and the number of FNCs).

\section{MCA $\mathbf{N}^{\circ} 1$ computing:}

The first MCA was computed on the basis of the 57 active variables. In other words, the MCA studies differences and similarities between farmers only on the basis of the 57 cited FPCs and FNCs.

Supplementary variables are used only to study how they correlate with the dimensions of the MCA. Detailed information on the MCA statistical method is available in Husson et al. (2017).

\section{Results of the MCA $\mathrm{N}^{\circ} \mathbf{1}$ :}

Results are presented in the following figures and table. As expected due to the sensitivity of MCAs to rare items, variability is mostly driven by the FPCs and FNCs that were rarely cited by farmers (such as R10, R11 and NC3 that were each reported by one farmer).

In order to reduce the influence of these rarely cited items, we therefore conducted a second MCA without them.
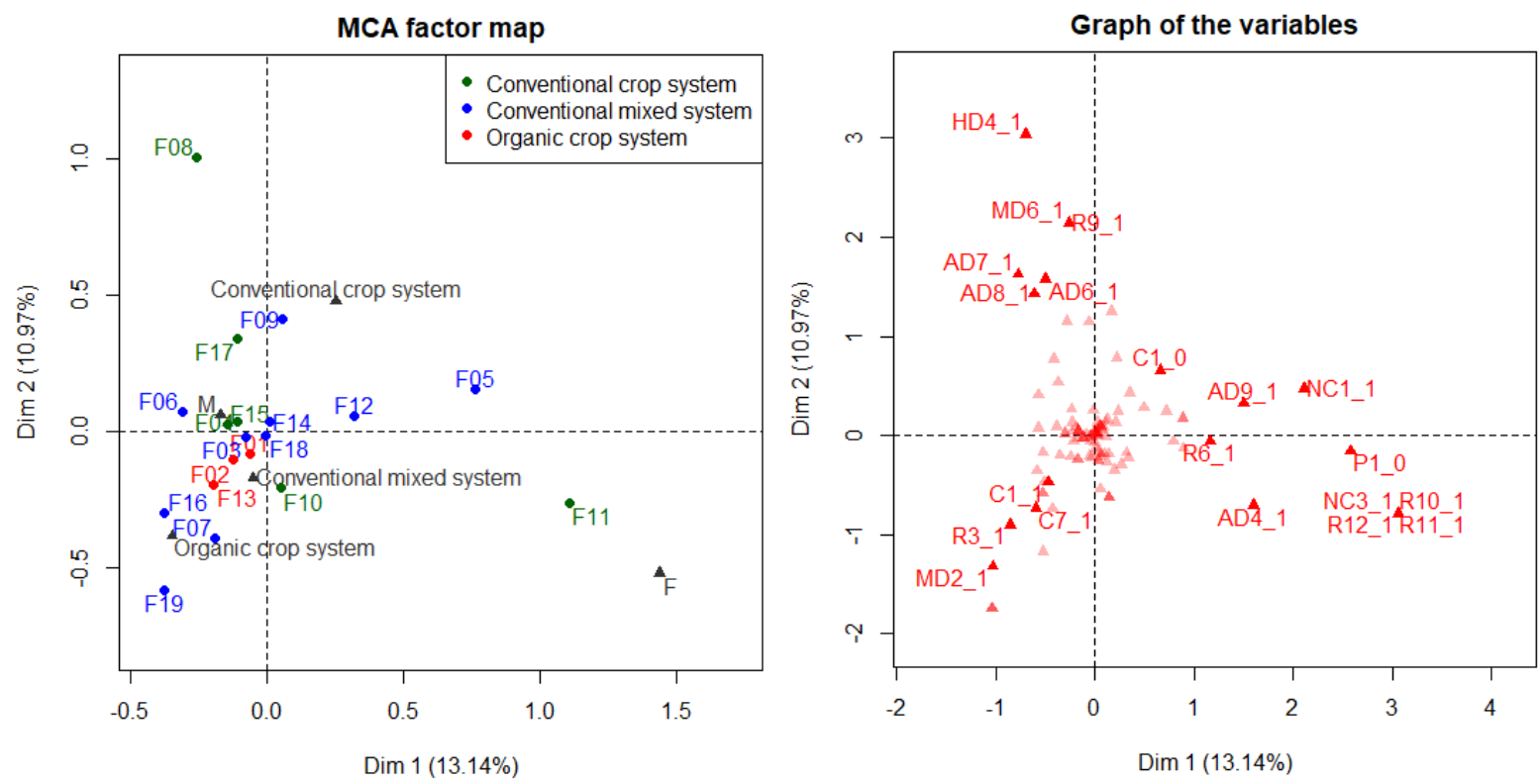

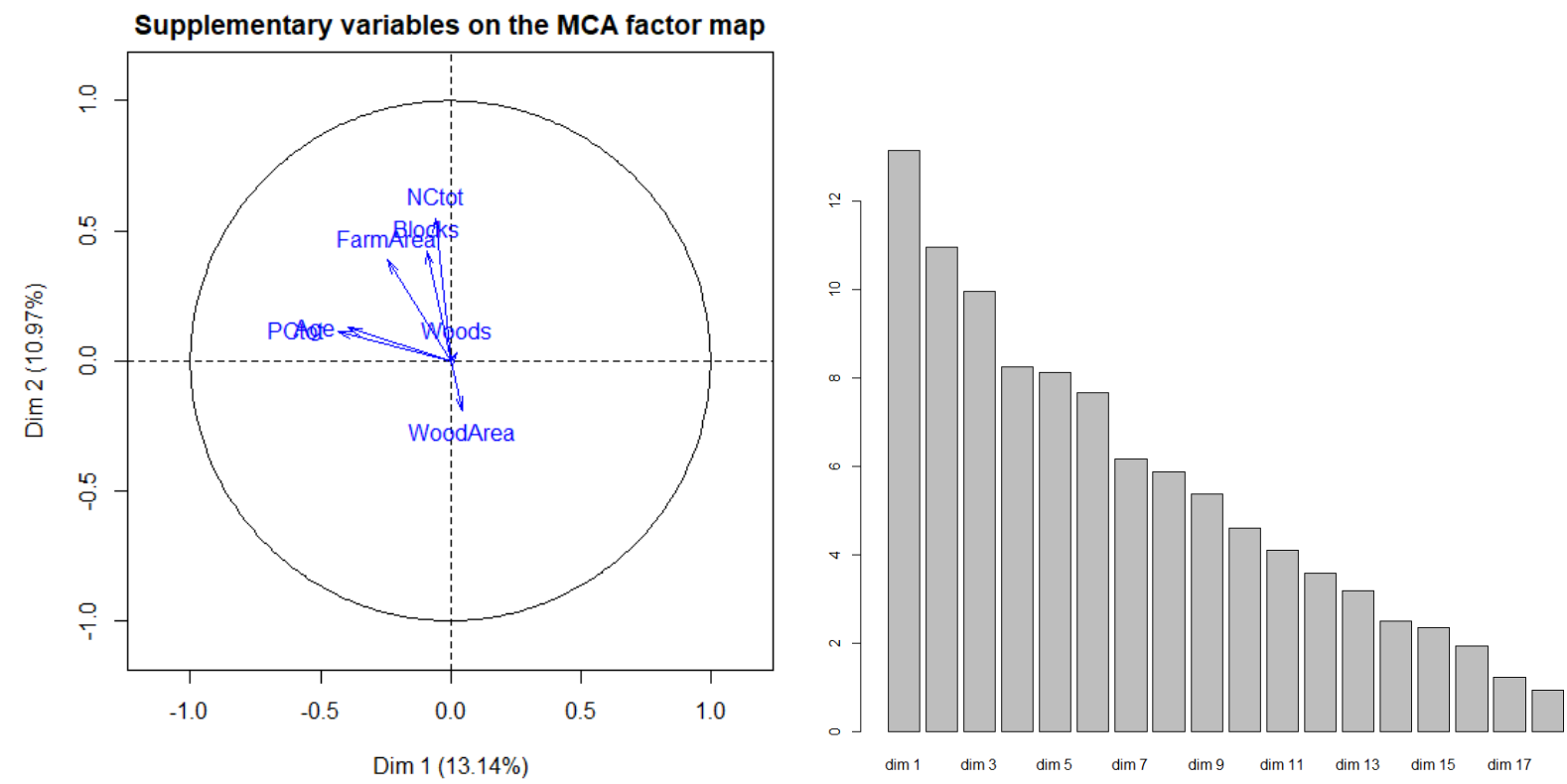

\begin{tabular}{|c|c|c|c|c|}
\hline $\mathbf{M C A}^{\circ} \mathbf{1}$ & \multicolumn{2}{|l|}{ Dim 1 (13.14\%) } & \multicolumn{2}{|l|}{$\operatorname{Dim} 2(10.97 \%)$} \\
\hline \multirow{2}{*}{$\begin{array}{c}\text { Individuals } \\
\text { (main contributors) }\end{array}$} & Id & $\operatorname{Cos} 2$ & Id & $\operatorname{Cos} 2$ \\
\hline & F08 & 0.612 & F08 & 0.671 \\
\hline \multirow[b]{2}{*}{$\begin{array}{l}\text { Active variables } \\
\text { (main contributors) }\end{array}$} & Id and name & Eta2 & Id and name & Eta2 \\
\hline & $\begin{array}{l}\text { P1-firewood } \\
\text { R2-oxygen and air quality } \\
\text { R10-humus production } \\
\text { R11-soil aeration } \\
\text { NC3-less area eligible to the PAC }\end{array}$ & $\begin{array}{l}0.782 \\
0.518 \\
0.518 \\
0.518 \\
0.518\end{array}$ & $\begin{array}{l}\text { MD6-expensive } \\
\text { management } \\
\text { HD4-risk for humans } \\
\text { R9-slow down water flows }\end{array}$ & $\begin{array}{l}0.541 \\
0.513 \\
0.541\end{array}$ \\
\hline \multirow{2}{*}{$\begin{array}{c}\text { Supplementary } \\
\text { qualitative variables } \\
\text { (main correlations) }\end{array}$} & Name & Eta2 & Name & Eta2 \\
\hline & - & - & - & - \\
\hline \multirow[b]{2}{*}{$\begin{array}{c}\text { Supplementary } \\
\text { quantitative variables } \\
\text { (main correlations) }\end{array}$} & Name & Cor & Name & Cor \\
\hline & $\begin{array}{l}\text { No of cited FPC } \\
\text { Farmer's age }\end{array}$ & $\begin{array}{l}-0.433 \\
-0.394\end{array}$ & $\begin{array}{l}\text { No of blocks } \\
\text { Farm area } \\
\text { No of cited FNC }\end{array}$ & $\begin{array}{l}0.424 \\
0.387 \\
0.546\end{array}$ \\
\hline
\end{tabular}




\section{MCA based on the FPC and FNC cited by at least two farmers}

\section{Dataset 2:}

A second MCA was performed on the basis of the FPCs and FNCs cited by at least two farmers. This choice was motivated by the sensitivity of MCAs to rare items highlighted in the first MCA. We therefore chose to remove from the analysis the FPCs and FNCs cited only once, which concerned a total of 12 FPCs and 12 FNCs (see Table 2 in the article). Our new dataset was therefore composed with 19 rows (one row for one farmer) characterized by a set of 42 variables, including:

- 33 active variables: these variables corresponded to the 33 FPCs and FNCs cited by at least two farmers.

- 9 supplementary variables (the same as in Dataset 1)

\section{Results of the $\operatorname{MCA} \mathbf{N}^{\circ} 2$ :}

Results are presented in the following figures and table. This analysis showed the contribution of two FPCs (R9 and C1) and two FNCs (MD6 and AD3) in the construction of the two first axes. Similarly, the MCA N ${ }^{\circ}$, MCA No2 identified F08 as an outlier. Moreover, it also showed the correlation of the size of the farm (No of farm blocks and farm area) and of the total number of cited FNCs and FPCs with the first two dimensions.

These results suggest that farmers with a larger farm (or in a conventional farming system) tended to cite more FNCs than farmers with a smaller farm.
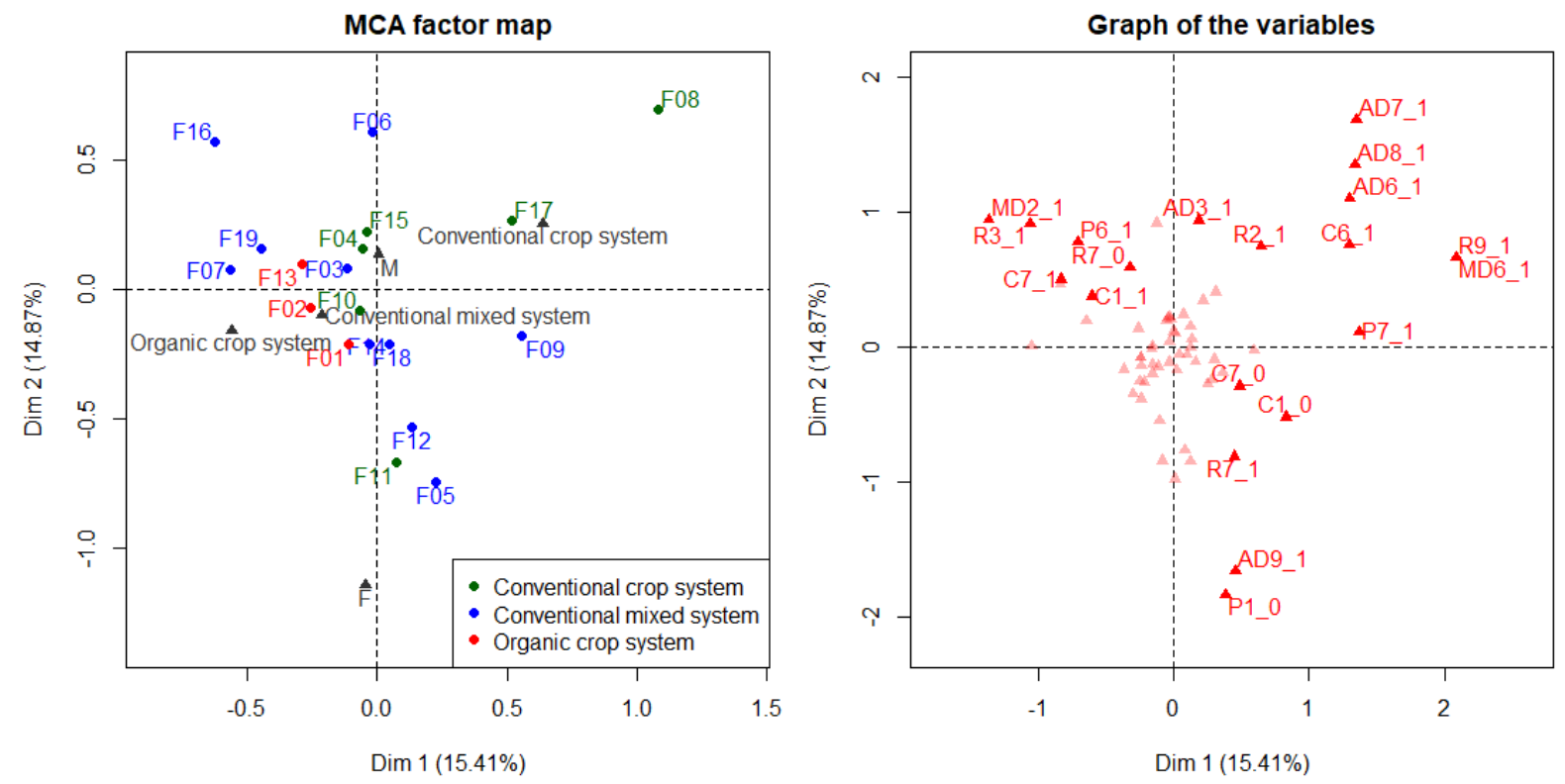

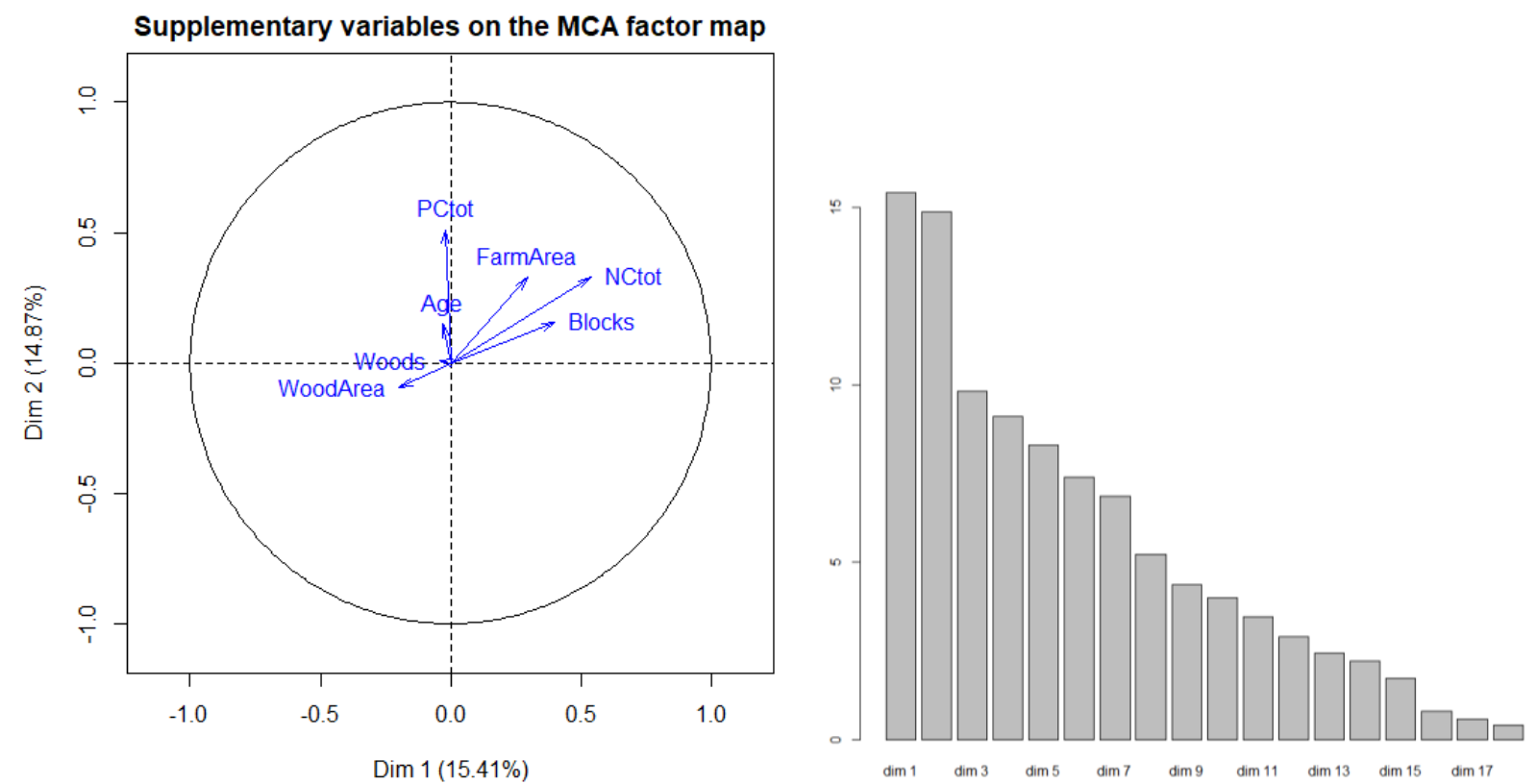

\begin{tabular}{|c|c|c|c|c|}
\hline $\mathbf{M C A ~ N}^{\circ} 2$ & \multicolumn{2}{|l|}{$\operatorname{Dim} 1(15.41 \%)$} & \multicolumn{2}{|l|}{$\operatorname{Dim} 2(14.87 \%)$} \\
\hline \multirow{2}{*}{$\begin{array}{c}\text { Individuals } \\
\text { (main contributors) }\end{array}$} & Id & $\operatorname{Cos} 2$ & Id & $\operatorname{Cos} 2$ \\
\hline & F08 & 0.579 & - & - \\
\hline \multirow[b]{2}{*}{$\begin{array}{l}\text { Active variables } \\
\text { (main contributors) }\end{array}$} & Id and name & Eta2 & Id and name & Eta2 \\
\hline & $\begin{array}{l}\text { MD6-expensive management } \\
\text { R9-slow down water flows } \\
\text { C1-landscape scenic }\end{array}$ & $\begin{array}{l}0.513 \\
0.513 \\
0.501 \\
\end{array}$ & AD3-additional workload & 0.514 \\
\hline \multirow{2}{*}{$\begin{array}{c}\text { Supplementary } \\
\text { qualitative variables } \\
\text { (main correlations) }\end{array}$} & Name & Eta2 & Name & Eta2 \\
\hline & - & - & - & - \\
\hline \multirow[b]{2}{*}{$\begin{array}{c}\text { Supplementary } \\
\text { quantitative variables } \\
\text { (main correlations) }\end{array}$} & Name & Cor & Name & Cor \\
\hline & $\begin{array}{l}\text { No of blocks } \\
\text { No of cited FNC }\end{array}$ & $\begin{array}{l}0.400 \\
0.539\end{array}$ & $\begin{array}{l}\text { No of cited FPC } \\
\text { No of cited FNC } \\
\text { Farm area }\end{array}$ & $\begin{array}{l}0.511 \\
0.328 \\
0.327\end{array}$ \\
\hline
\end{tabular}




\section{MCA based on the classes of FPC and FNC}

Because of the low number of observations (19 farmers) compared to the high number of active variables (33 FPCs/FNCs for the $\mathrm{MCA} \mathrm{N}^{\circ}$ 2), we performed additional MCA on the basis of the classes of FPC and FNC. Indeed, using classes of FPC and FNC instead of FPCs and FNCs themselves allowed reducing the number of variables used to describe farmers from 57 (Dataset 1) to 31 (Dataset 3).

\section{Dataset 3:}

A third MCA was performed on the basis of the classes of FPC and FNC associated with farmers' perceived FPCs and FNCs (see Table 2 in the article). The dataset 3 was therefore composed with 19 rows (one row for one farmer) characterized by a set of 40 variables, including:

- 31 active variables: these variables corresponded to the 31 classes of FPC and FNC defined in the Table 2 of the article. For the farmer $i$ and the variable $j$, the cell $[i, j]$ received the value " 1 " if the farmer $i$ cited at least one FPC (or FNC) belonging the class corresponding to the variable $j$, and " 0 " otherwise.

- 9 supplementary variables (the same as in Datasets 1 and 2)

\section{Results of the MCA N ${ }^{\circ} 3$ :}

Results are presented in the following figures and table.

F05 was identified as the main contributor of the axis 1.

Main contributing variables to the two first axis were relative to 2 classes of FPC and 3 classes of FNC.

The only supplementary variable that tended to correlate with the MCA axes was the farming system.
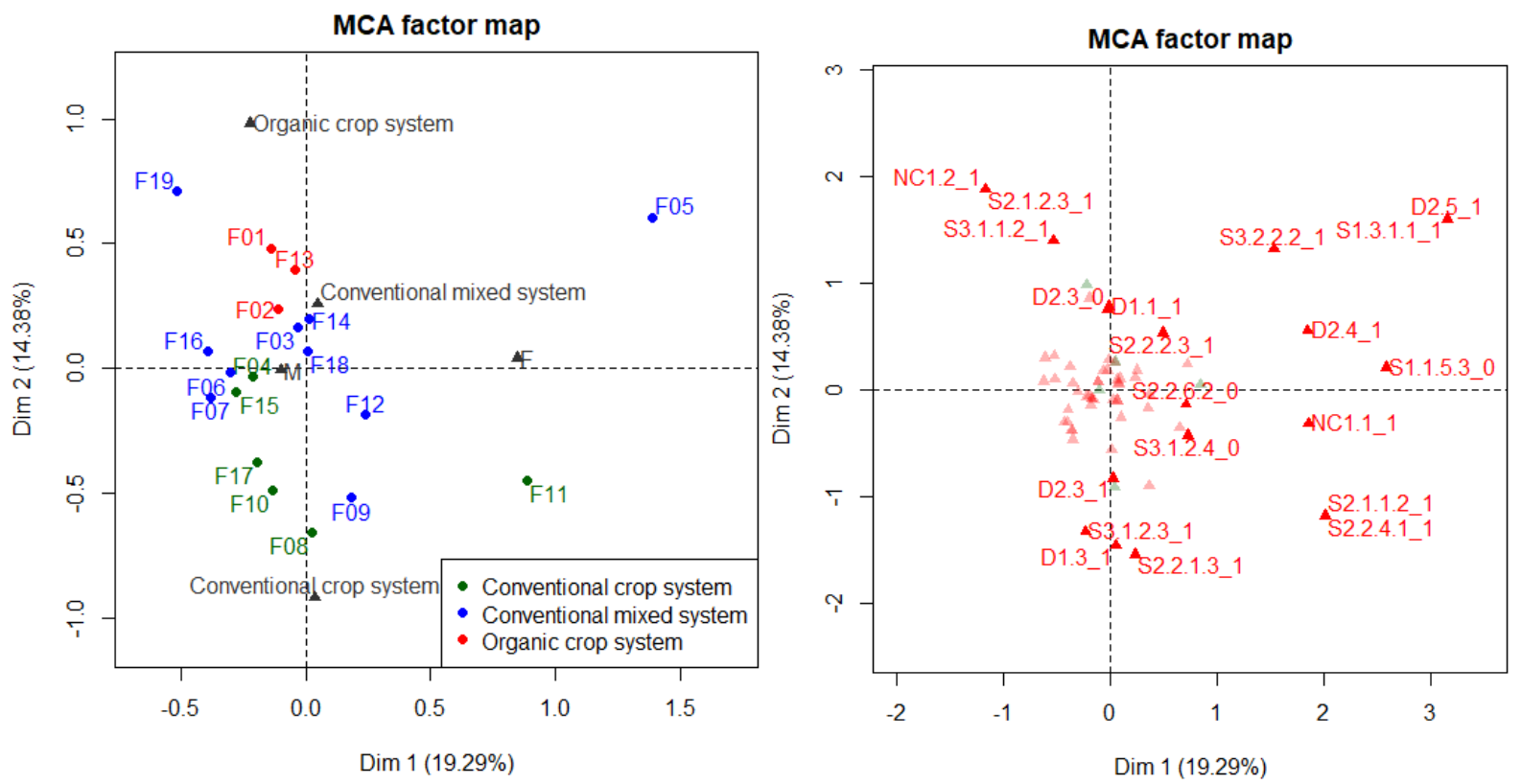


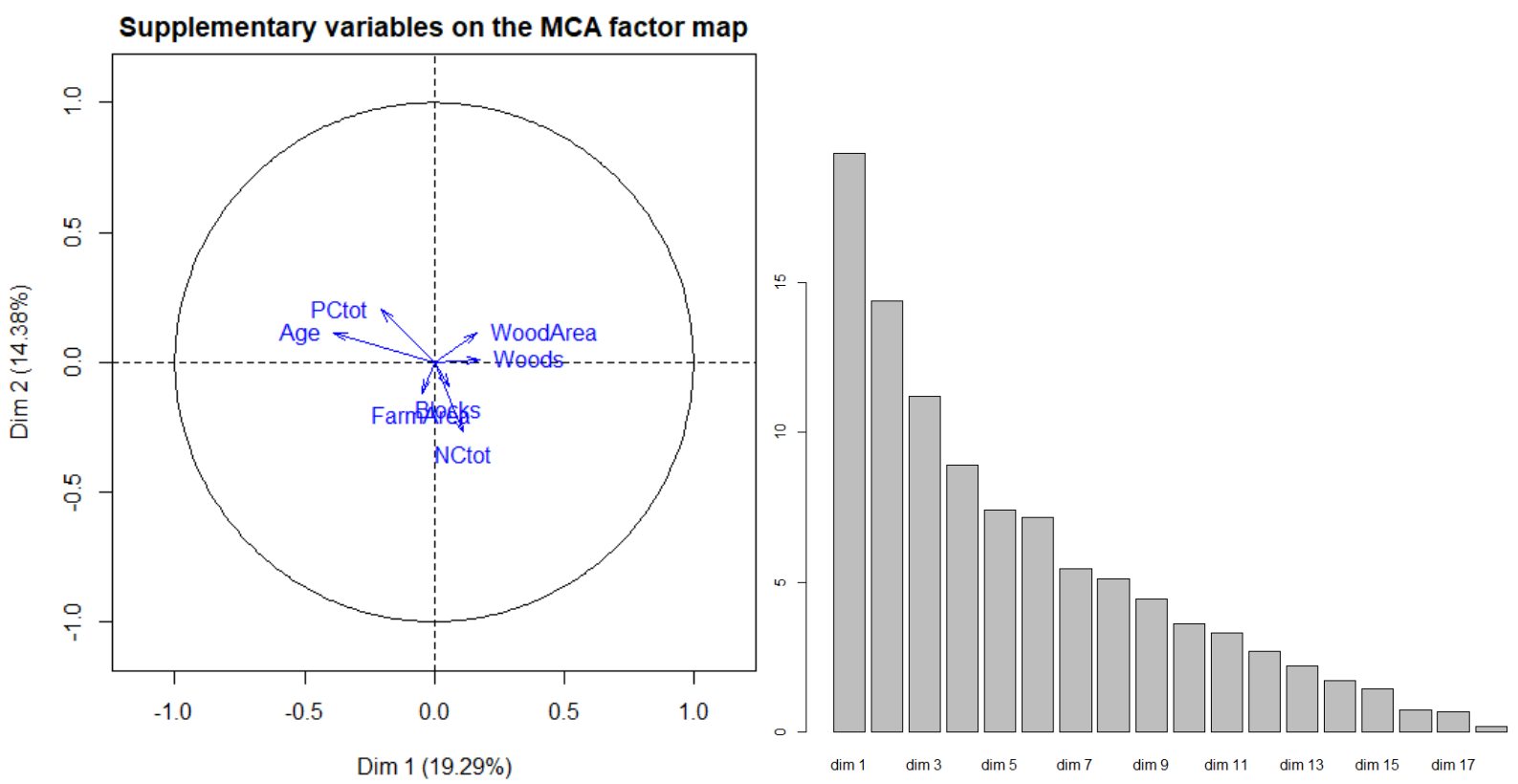

\begin{tabular}{|c|c|c|c|c|}
\hline MCA N'3 & \multicolumn{2}{|l|}{ Dim $1(19.29 \%)$} & \multicolumn{2}{|c|}{$\operatorname{Dim} 2(14.38 \%)$} \\
\hline \multirow{2}{*}{$\begin{array}{c}\text { Individuals } \\
\text { (main contributors) }\end{array}$} & Id & $\operatorname{Cos} 2$ & Id & $\operatorname{Cos} 2$ \\
\hline & F05 & 0.715 & - & - \\
\hline \multirow[b]{2}{*}{$\begin{array}{l}\text { Active variables } \\
\text { (main contributors) }\end{array}$} & Id and name & Eta2 & Id and name & Eta2 \\
\hline & $\begin{array}{l}\text { D2.5-competition for land } \\
\text { S1.1.5.3-wild plant for energy } \\
\text { S1.3.1.1-biomass for agriculture } \\
\text { NC1.1-leglislative constraints }\end{array}$ & $\begin{array}{l}0.554 \\
0.787 \\
0.554 \\
0.650\end{array}$ & $\begin{array}{l}\text { D2.3-decrease in crop } \\
\text { production }\end{array}$ & 0.514 \\
\hline \multirow{2}{*}{$\begin{array}{l}\text { Supplementary } \\
\text { qualitative variables } \\
\text { (main correlations) }\end{array}$} & Name & Eta2 & Name & Eta2 \\
\hline & - & - & Farming system & 0.455 \\
\hline \multirow{2}{*}{$\begin{array}{c}\text { Supplementary } \\
\text { quantitative variables } \\
\text { (main correlations) } \\
\end{array}$} & Name & Cor & Name & Cor \\
\hline & - & - & - & - \\
\hline
\end{tabular}




\section{MCA based on the classes of FPC and FNC cited at least twice}

Finally, in order to take into account the sensitivity of MCAs to rare items, we performed a fourth MCA on the basis of the classes of FPC and FNC cited by at least two farmers. This MCA is the one presented in the main article.

\section{Dataset 4:}

A fourth MCA was performed on the basis of the classes of FPC and FNC cited by at least two farmers. We removed from the dataset 3 the classes FPC and FNC cited only once, which concerned a total of 6 classes of FPC and FNC (see Table 2 in the article). The dataset 4 was therefore composed with 19 rows (one row for one farmer) characterized by a set of 34 variables, including:

- 25 active variables: these variables corresponded to the 25 classes of FPC and FNC cited by at least two farmers. 9 supplementary variables (the same as in all previous Datasets)

\section{Results of the MCA N ${ }^{\circ}$ :}

Results of the MCA are presented in the following figures and table, as well as in the main article. The main observation that contributes to the first axis is F05.

The active variables contributing to the first two dimensions of the MCA are 2 classes of FPC and 3 classes of FNC.

Finally, four supplementary variables tended to correlate with the axes displaying the highest variability observed in farmers' perceptions. Three of these were associated with socio-demographic characteristics (farm area, farming system and farmer's age) while one was the number of FNCs cited during interviews.

Results corroborate previous MCAs and indicate an influence of the farming system and farm area on farmers' perceptions.

\section{References}

Husson, F., Lê, S., Pages, J., 2017. FactoMineR: Multivariate Exploratory Data Analysis and Data Mining.
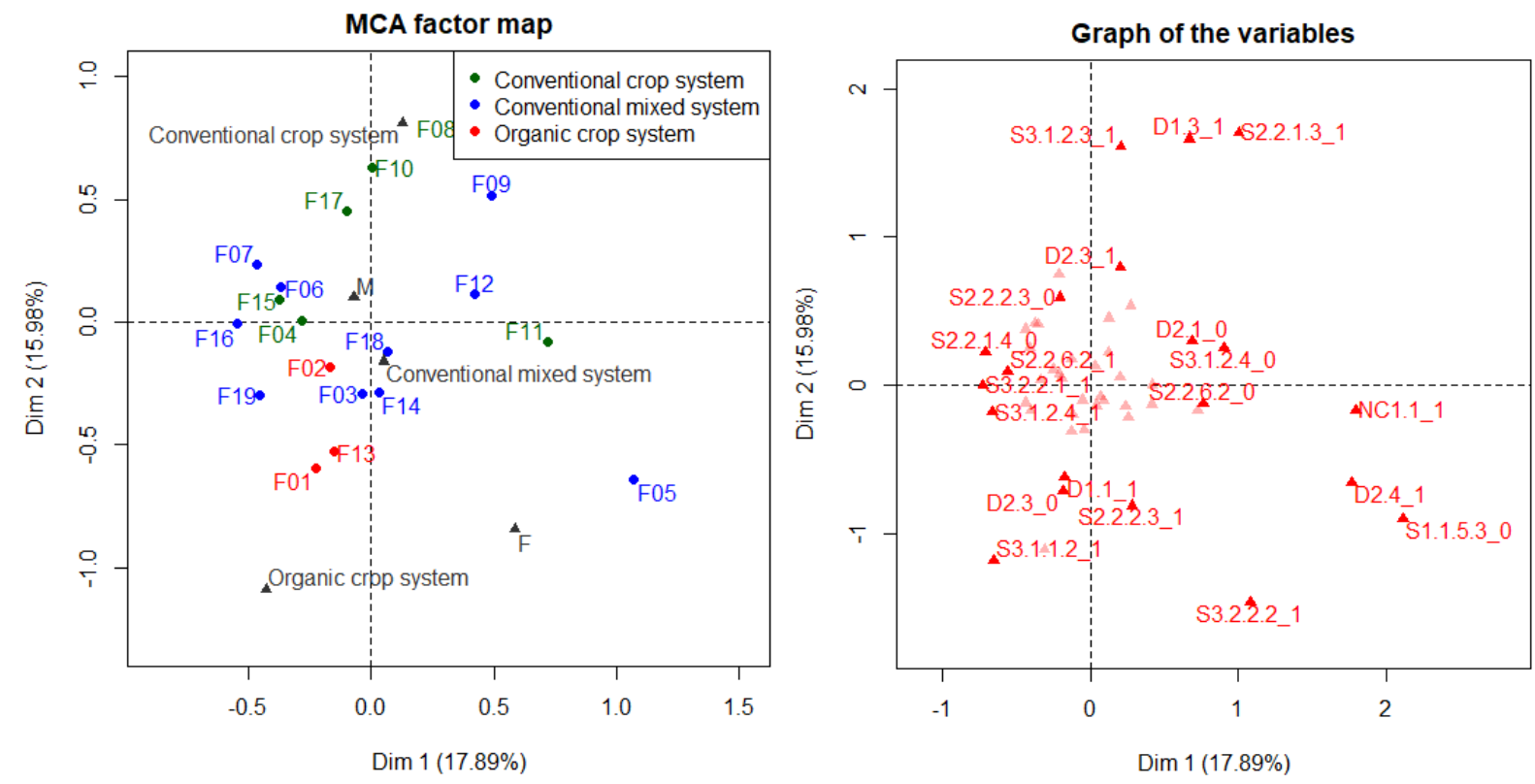

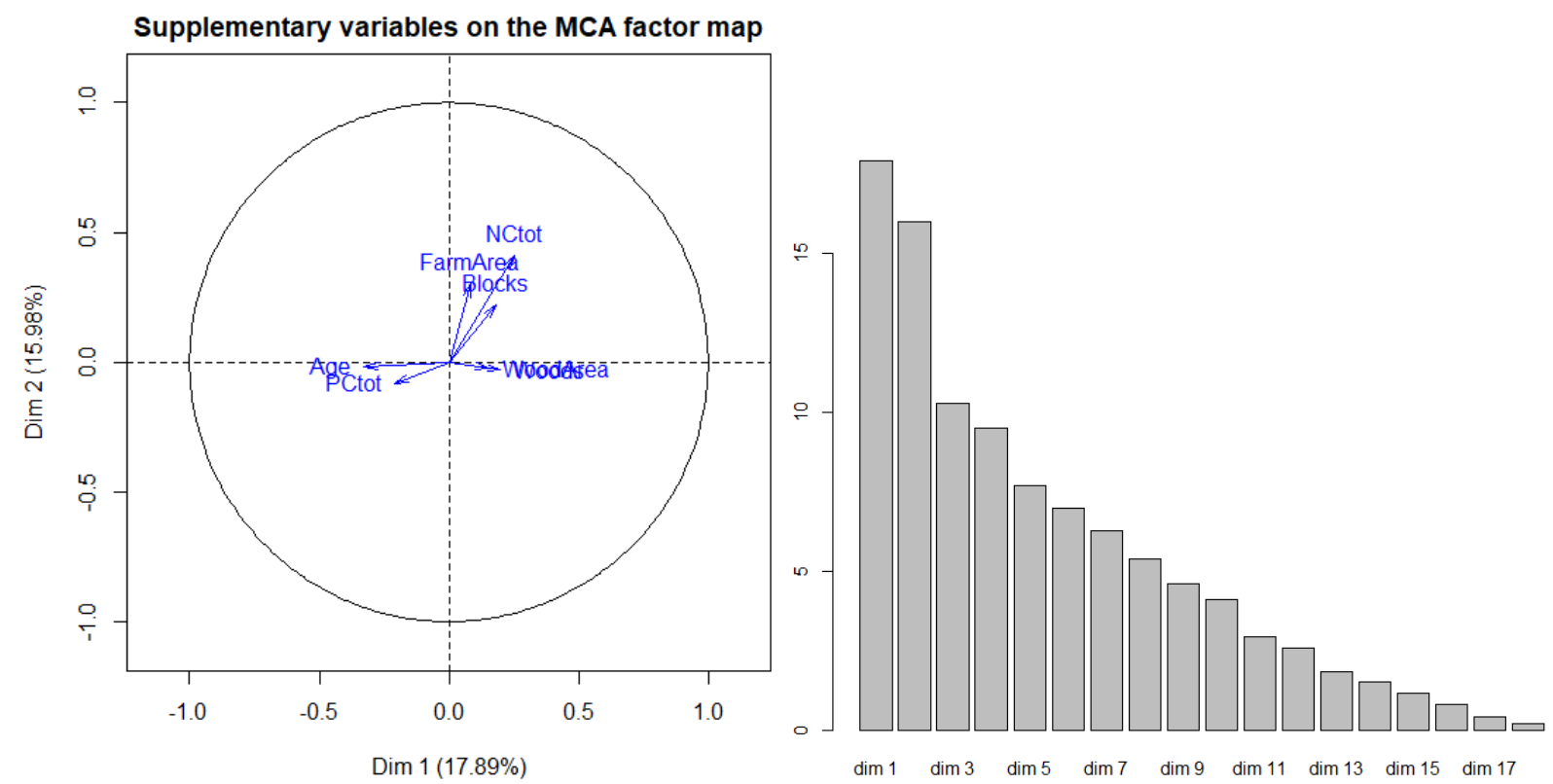

\begin{tabular}{|c|c|c|c|c|}
\hline MCA N $^{\circ} 4$ & \multicolumn{2}{|l|}{ Dim $1(17.89 \%)$} & \multicolumn{2}{|c|}{ Dim $2(15.98 \%)$} \\
\hline \multirow{2}{*}{$\begin{array}{c}\text { Individuals } \\
\text { (main contributors) }\end{array}$} & Id & Cos2 & Id & Cos2 \\
\hline & F05 & 0.609 & - & - \\
\hline \multirow[b]{2}{*}{$\begin{array}{l}\text { Active variables } \\
\text { (main contributors) }\end{array}$} & Id and name & Eta2 & Id and name & Eta2 \\
\hline & $\begin{array}{l}\text { S1.1.5.3-wild plant for energy } \\
\text { S3.1.2.4-aesthetic experiences } \\
\text { NC1.1-leglislative constraints }\end{array}$ & $\begin{array}{l}0.527 \\
0.596 \\
0.607\end{array}$ & $\begin{array}{l}\text { D2.3-decrease in crop } \\
\text { production } \\
\text { D1.3-economic costs }\end{array}$ & $\begin{array}{l}0.570 \\
0.517\end{array}$ \\
\hline \multirow{2}{*}{$\begin{array}{c}\text { Supplementary } \\
\text { qualitative variables } \\
\text { (main correlations) }\end{array}$} & Name & Eta2 & Name & Eta2 \\
\hline & - & - & Farming system & 0.408 \\
\hline \multirow{2}{*}{$\begin{array}{l}\text { Supplementary } \\
\text { quantitative variables } \\
\text { (main correlations) }\end{array}$} & Name & Cor & Name & Cor \\
\hline & Farmer's age & -0.327 & $\begin{array}{l}\text { Farm area } \\
\text { No of cited FNC }\end{array}$ & $\begin{array}{l}0.302 \\
0.411 \\
\end{array}$ \\
\hline
\end{tabular}

